\title{
Host factors influencing susceptibility to HIV infection and AIDS progression
} Juan Lama*1,2 and Vicente Planelles ${ }^{3}$

\begin{abstract}
Address: ${ }^{1}$ La Jolla Institute for Molecular Medicine, 4570 Executive Drive, Suite 100, San Diego, California 92121, USA, ${ }^{2}$ RetroVirox, Inc. 4570 Executive Drive, Suite 100, San Diego, California 92121, USA and ${ }^{3}$ Department of Pathology, University of Utah School of Medicine, 15 North Medical Drive East \#2100 - Room 2520, Salt Lake City, Utah 84112, USA
\end{abstract}

Email: Juan Lama* - jlama@retrovirox.com ; Vicente Planelles - vicente.planelles@path.utah.edu

* Corresponding author

Published: 25 July 2007

Retrovirology 2007, 4:52 doi:10.1 186/1742-4690-4-52

This article is available from: http://www.retrovirology.com/content/4/I/52

(C) 2007 Lama and Planelles; licensee BioMed Central Ltd.

This is an Open Access article distributed under the terms of the Creative Commons Attribution License (http://creativecommons.org/licenses/by/2.0), which permits unrestricted use, distribution, and reproduction in any medium, provided the original work is properly cited.
Received: 16 May 2007

Accepted: 25 July 2007

\begin{abstract}
Transmission of HIV first results in an acute infection, followed by an apparently asymptomatic period that averages ten years. In the absence of antiretroviral treatment, most patients progress into a generalized immune dysfunction that culminates in death. The length of the asymptomatic period varies, and in rare cases infected individuals never progress to AIDS. Other individuals whose behavioral traits put them at high-risk of HIV transmission, surprisingly appear resistant and never succumb to infection. These unique cases highlight the fact that susceptibility to HIV infection and progression to disease are complex traits modulated by environmental and genetic factors. Recent evidence has indicated that natural variations in host genes can influence the outcome of HIV infection and its transmission. In this review we summarize the available literature on the roles of cellular factors and their genetic variation in modulating HIV infection and disease progression.
\end{abstract}

\section{Background}

The period of asymptomatic disease after HIV-1 infection averages about ten years, although it may vary greatly among infected subjects [1]. The existence of attenuated viral strains that fail to induce disease in animal models has long been known. Similarly, it is now widely accepted that human allelic variants for certain genes can influence the susceptibility to HIV-1 infection [2,3]. Supporting a role for genetic factors in the host, several studies have shown that susceptibility to HIV-1 in vitro largely varies among individual donors. Conversely, primary cells from homozygotic twins display much less variation in their permissivity to infection [4-8].

Like all viruses, HIV-1 must usurp the cellular machinery at multiple steps to complete a productive cycle. The virus enters cells by fusing with the cellular membrane, taking advantage of receptor and co-receptor host proteins, which otherwise play important roles in immunity and inflammation. Then, the viral genetic material is delivered into the cytoplasm in the form of a nucleoprotein core. The viral RNA genome is copied into DNA, transported to the cell nucleus, and integrated in the host chromosome. The proviral HIV-1 DNA is transcribed into viral mRNAs, which are then processed and exported to the cytoplasm. Upon translation, viral products are transported to budding sites where virions are assembled together with viral RNA. For each of these steps, HIV-1 relies on cellular proteins. Only a fraction of these host proteins have been identified, but their role in the HIV-1 life cycle is currently a subject of intense investigation. 


\section{Approaches to study HIV disease progression} Several approaches have been used to study HIV pathogenesis in vivo. The availability of non-human primate models has largely advanced our understanding of the field. Studies with animal models have highlighted the importance of the so-called viral "accessory genes" in HIV disease progression. These genes were initially deemed non-essential in in vitro studies because the virus would be able to replicate despite their removal from the viral genome [9]. Despite the usefulness of animal models to define viral determinants of pathogenesis, the genetic differences between human and non-human primates, have made the latter less amenable for the study the role of host factors.

Long-term nonprogressors (LTNP) have provided a unique opportunity to study the mechanisms of HIV disease. LTNPs are HIV-infected individuals who have lived free of symptoms for extended periods of time, in the absence of antiretroviral treatment. A standard criterion for LTNP status is to have had a documented infection for ten years or more, stable CD4-positive T cell counts above 500 cells/ml, and plasma viral load below 10,000 RNA copies/ml. Depending on the definition of "nonprogression" used, this population has been estimated to represent $2-4 \%$ of all infected patients [10]. The recruitment of LTNP cohorts is a formidable task, because until recently, most patients with well documented clinical histories had been treated before the onset of symptoms.

An additional approach to examine disease progression is to investigate highly exposed uninfected (EU) individuals. EUs are subjects who resist HIV infection and seroconversion, despite being at high-risk for transmission. EU cohorts have been gathered from groups of intravenous drug users (IDU), sex workers, children born to seropositive mothers, individuals performing unprotected sex with multiple partners, and health care workers undergoing accidental exposure to the virus [11].

Important insight into HIV pathogenesis can also be gained by studying the natural course of infection in seropositive patients. Clinical variables (decline in CD4 counts, increase in viral load) have been used to monitor the rate of progression to disease in untreated patients, or to establish prognosis in terms of virologic and immunologic success in patients following antiretroviral regimes. These variables can be statistically associated with host genotypic variants or specific phenotypic traits.

Finally, the study of healthy HIV-seronegative patients who may bear genetic markers of interest, can also shed light into the mechanisms of HIV pathogenesis. The role of cellular factors influencing HIV replication and immunity can be addressed by exposing primary cells from healthy seronegative individuals to virus in vitro. Likewise, statistical associations between haplotypes or singlenucleotide polymorphisms (SNP) can be drawn by monitoring the extent of viral replication in vitro. When available, genetic associations with the rate of replication in these ex-vivo models can also be validated with in vivo data monitoring disease progression [12].

Factors influencing susceptibility to infection and the course of disease can be grouped into three categories: 1) viral factors determining the replicative properties of the virus or its ability to escape immune responses; 2 ) cellular factors modulating the innate or acquired immune responses to infection; and 3) cellular factors co-operating with viral products that govern the ability of the virus to replicate in human cells. Thus, the rate at which an untreated HIV-infected patient progresses to AIDS may be explained by a combination of these factors, which ultimately dictate how fast HIV replicates and/or how efficiently it overcomes the immune defenses posed by the host. Below, we will discuss cellular factors influencing various steps of the HIV life cycle, and those modulating the innate immune response. The role of the HLA system in AIDS progression is beyond the scope of this review, and has been amply discussed in other reviews [13-15].

\section{Host factors modulating viral entry The HIV-I co-receptors: CCR5 and CXCR4}

Entry into target cells occurs by a multi-step process that culminates with the fusion of viral and cellular membranes. HIV-1 utilizes CD4 as its primary receptor. Binding to CD4 is followed by conformational changes in the viral envelope that lead to the engagement of one of the viral co-receptors (CCR5 or CXCR4) [16]. Based on their functionality in vitro, other chemokine receptors may also work as HIV-1 co-receptors. Among them are CCR2, CCR3, CCR8, CCR9, CXCR6, CX3CR1, ChemR23, APJ, and RDC1. However, CCR5 and CXCR4 constitute the major co-receptors in vivo (for a recent review see [17]).

CXCR4 was the first co-receptor identified [18]. Afterwards, the role of CCR5 in HIV-1 infection was soon elucidated [19-23]. Soon after these findings, researchers sought genetic polymorphisms that could confer protection to HIV-1 infection [19-21,23,24]. These studies characterized the CCR5 $\Delta 32$ allele, which has been unequivocally associated with protection to HIV-1 infection in homozygotic individuals [24-26]. This discovery provided the first conclusive evidence for the existence of genetic resistance to HIV-1 infection. CCR $5 \Delta 32$ expresses a truncated co-receptor that is not transported to the cell surface and thus is incompetent for viral entry [27]. Individuals homozygous for the $\Delta 32$ allele seem to have a normal life expectancy, although immunological differences have been reported, which may influence the outcome of 
infections with other pathogens, such as West Nile and hepatitis $C$ virus (reviewed in $[17,28]$ ). The apparent lack of immunological dysfunction in individuals with the homozygous $\Delta 32$ genotype may be explained by the functional redundancy in the chemokine receptors and their ligands. The CCR $5 \Delta 32$ allele occurs at a frequency of 4$15 \%$ in the Caucasian population, with higher frequencies in Northern European populations. However, the CCR5 $\triangle 32$ allele is rarely found in Asians and Africans. Approximately $1 \%$ of Caucasians carry two copies of the $\Delta 32$ allele [29]. These individuals are overrepresented in cohorts of high-risk HIV-seronegative individuals (EUs) $[25,30,31]$. Protection against HIV-1 infection in homozygous CCR $5 \Delta 32$ individuals, however, is not complete. Although rare, infections of homozygous CCR5 $\Delta 32$ have been reported, but always in patients infected with virus strains utilizing the CXCR4 co-receptor [32-37]. Other studies have reported increased frequencies of CCR5 432 heterozygotes among LTNP, and in patients progressing to disease at slower than normal rates [38-41]. However, these associations have not been observed in all cohorts, suggesting that the CCR5 $\Delta 32$ allele alone may not universally slow progression to AIDS [42-45]. Genetic differences among the ethnicities evaluated, or different transmission routes in the studied cohorts may explain these discrepancies.

The observation that high level of CCR5 expression on CD4-positive primary $\mathrm{T}$ cells is associated with high viral loads and accelerated disease progression further highlights the contribution of CCR 5 to disease progression $[46,47]$. Generally, lymphocytes from $\Delta 32$ heterozygous individuals express lower surface levels of CCR5, as compared to those observed on cells from individuals homozygous for the wild type gene [48]. In the previous CCR5 expression in heterozygous individuals was lower than the expected $50 \%$, relative to wild-type homozygous. This observation led the authors to hypothesize that the truncated co-receptor may dimerize with the full-length protein and interfere with its transport.

Other mutations in the CCR5 coding region have been described. Some of them introduce frame-shifts that result in truncated proteins that, similarly to the $\Delta 32$ variant, fail to be transported to the cell surface (e.g., FS299). Other mutations (e.g. C20S and C269F) affect the formation of disulfide bridges, altering surface expression of the receptor and the ability to bind ligands [49]. Some mutations result in undetectable or very low levels of surface receptor (C269F, G106R, C101X). Unlike $\Delta 32$, most of these CCR5 variants are relatively rare (frequencies below 1-2\%) and only present in specific populations. Thus, their role in HIV-1 disease progression has not been properly established $[17,49,50]$. Interestingly, the rare C20S, C101X (also called m303), and T303A alleles are over-repre- sented in EU individuals also carrying the more common CCR5 $\Delta 32$ allele $[51,52]$. These findings suggest that alleles that may, in the context of a wild type allele, have a weak effect, may exert a more profound protection in combination with CCR $5 \Delta 32$.

Genetic variants have also been described in the CCR5 promoter. Most changes are single base substitutions that could potentially alter the level of expression. CCR5P1, one of the multi-site haplotypes identified in the CCR5 promoter, is composed of 13 distinct SNPs. This haplotype has been associated with faster progression to AIDS in individuals carrying the wild type coding region for CCR5 and CCR2, and homozygous for CCR5P1 [53]. A similar association with rapid progression has been reported for an $\mathrm{A} / \mathrm{G}$ polymorphism located in the first CCR5 intron. Individuals containing $A$ in both copies (59029-A/A) progress more rapidly to AIDS [54]. Interestingly, the $\Delta 32$ phenotype seems to be largely influenced by the presence of mutations in the CCR5 promoter region, with some combinations resulting in poor coreceptor expression and protection against HIV-1 transmission [55].

Antibodies against CCR5 may provide another mechanism of interference with CCR5 function in vivo. AntiCCR5 antibodies have been reported in a subset of LTNP $(24 \%)$ but not in other populations studied. These antibodies induce internalization of the co-receptor in vivo and block HIV entry of R5 strains in vitro [56]. Anti-CCR5 antibodies have also been detected in the milk of $66 \%$ and $83 \%$ of HIV-seronegative and seropositive women, respectively. Anti-CCR5 antibodies purified from these women also protect against infection of R5 strains in vitro [57]. These findings suggest that some degree of protection against vertical transmission of HIV-1 may be mediated by anti-CCR 5 antibodies present in the milk. The mechanism governing induction of anti-CCR5 antibodies in humans is unknown, but these observations underscore the interesting prospect of preventing HIV transmission with vaccines targeting the CCR5 co-receptor, an approach that is being examined in murine models [58].

The compelling evidence supporting the role of CCR $5 \Delta 32$ in protection from disease in homozygous individuals, the apparently healthy characteristics of these individuals, and the ubiquitous presence of CCR5-tropic HIV-1 strains throughout most of the disease, have prompted efforts to target CCR5 with novel antiretroviral therapies. To date, at least nine small-molecule inhibitors and monoclonal antibodies are under development, being tested in clinical trials, or awaiting imminent FDA review [59,60]. Aplaviroc, maraviroc, and vivriviroc are noncompetitive, allosteric CCR5 antagonists that have been tested in large clinical trials. Unlike CCR5 agonists (e.g. PSC-RANTES), 
none of these compounds induces signaling through CCR5 or receptor internalization. There are potential problems associated with the treatment with CCR5 antagonists. For example, use of this therapy may lead to the emergence of CXCR4-tropic strains, which could accelerate disease progression [61]. In addition, CCR5 inhibition could interfere with the normal immune and inflammatory responses. Despite the apparent normal phenotype of CCR5 32 homozygotic individuals, it is not clear how interference with CCR5 will affect the already impaired immune systems in HIV-infected patients. Thus, many questions need to be answered before CCR5 inhibitors are safely used in humans.

\section{CCR2 and CX3CRI}

Despite the pivotal role of CCR5 as the major co-receptor for HIV-1, polymorphisms in other chemokine receptors appear to also exert a certain degree of protection against HIV-1 infection and/or disease progression. The most compelling evidence comes from the CCR2-64I variant, an allelic variant in which isoleucine 64 is replaced by valine [62]. Heterozygous individuals for CCR2-64I progress slower to AIDS, although no clear effect in protecting against HIV-1 infection has been documented. Not all studies have confirmed this association [43,63], and the effect of the CCR2-64I remains controversial. Intriguingly, the CCR2 receptor is used only by a few strains in vivo, thus the mechanism of action of the CCR2-64I variant is unknown. CCR2 lies $17.5 \mathrm{~kb}$ upstream of the CCR5 promoter, and it has been suggested that the 64I variant may be in linkage disequilibrium with genetic variations in the CCR5 region [64]. To date, most reports have observed no changes in the levels of CCR2 or CCR5 surface expression in CCR2-64I individuals [64,65]. One study, however, reported lower levels of surface CCR5 and suggested, though it did not prove, that CCR2-64I may bind with increased affinity to CCR5 intracellularly and thus interfere with the expression of CCR5 at the cell surface [66]. Another report suggested interference with CXCR4 as an alternative explanation, demonstrating that the 64I gene product dimerizes with CXCR4 more efficiently than the wild-type CCR2 [67].

CX3CR1, the receptor for the chemokine fractalkine [68], has also been associated with HIV-1 disease progression. Its role as a co-receptor for HIV-1 in vivo is not clear, but it has been suggested that CX3CR1 could affect HIV-1 replication by influencing the recruitment of immunomodulatory cells. Two SNPs have been identified that form part of the haplotype I249-M280. Originally, this haplotype was found at higher frequency in a cohort of Caucasian HIV-infected patients progressing to AIDS faster than normal [69]. These results were later confirmed with a cohort of HIV-infected children [70]. In another study evaluating individuals entering HAART treatment during one year, the I249 polymorphism was found at a higher frequency among those displaying early immunological failure, estimated as a decline in CD4 counts [71]. A study with a Spanish cohort found the haplotype composed of I249 and T280 was overrepresented among LTNPs, as compared to normal progressors, but the same study reported no significant effect on the distribution of the M280 SNP [72]. Adding controversy to the role of CX3CR1, the results with the M280 SNP have not been confirmed in other studies [73-75]. A possible explanation has been proposed to explain these discrepancies, as follows. Due to the deleterious effect of the M280 allele, this SNP may have disappeared from some cohorts due to premature death of patients before recruitment. The low frequency of the allele observed in a French cohort supports this explanation [76]. Additional studies will be needed to address the importance of CX3CR1 in HIV-1 pathogenesis and to understand the biological basis behind the observed phenotypes.

\section{The phenotypic switch: Does co-receptor usage influence disease progression?}

The HIV-1 strains that are most often responsible for transmission utilize CCR5. These so-called M-tropic (R5) viruses predominate during the asymptomatic stage and infect CD4-positive lymphocytes and macrophages. In approximately half of the patients with advanced disease, the viral quasiespecies are dominated by viruses that utilize CXCR4 [77]. These viruses are called T-tropic (or X4) and infect macrophages inefficiently $[78,79]$. The emergence of $\mathrm{X} 4$ viruses ("phenotypic switch") is associated with accelerated decline in CD4-positive lymphocyte counts and faster progression to disease. Thus, the phenotypic switch has been thought of as a causal factor leading to accelerated disease. In support of a role for X4 viruses in disease progression, studies with macaques infected with SIV carrying CXCR4-tropic HIV-1 envelope (SHIV chimera) display rapid loss of CD4 counts and develop AIDS faster than the R5 counterpart [80].

It is possible that the emergence of $\mathrm{X} 4$ viruses may be the consequence, rather than the cause of immune deterioration and disease progression [77]. Supporting this idea, not all patients who develop full-blown AIDS experience the switch to $\mathrm{X} 4$ viruses, and yet the R5 strains present in these individuals late during disease are more pathogenic than early viruses [81]. The mechanisms governing HIV co-receptor switch are poorly understood. Furthermore, it is not clear whether the so called "switch", emergence of $\mathrm{X} 4$ tropic viruses, occurs by acquisition of mutations in R5 envelopes, or rather $\mathrm{X} 4$ viruses are transmitted during infection but replicates poorly during the asymptomatic stages. The emergence of viruses with dual tropism (R5$\mathrm{X} 4)$ suggest the accumulation of gradual changes. More sensitive phenotypic assays able to detect very small frac- 
tions of $\mathrm{X} 4$ and dual-tropic viruses will allow us to understand how viral tropism changes throughout infection. Several selective forces have been suggested to explain why the emergence of $\mathrm{X} 4$ strains is restricted during initial phases of infection (reviewed in [82]). High levels of CCR5-positive activated and memory cells present in gutassociated lymphoid tissue, an important site during acute infection, may provide fertile ground for the proliferation of R5 tropic strains. In addition, the constitutive levels of expression of SDF-1 in mucosal tissues could act to restrict transmission of $\mathrm{X} 4$ viruses [83]. This, however, contradicts the observation that parenteral transmission of HIV-1 also results in the early predominance of R5 viruses. Clearly, some selective forces must keep X4 viruses under control at early stages of infection. Later in infection, the selective pressure achieved by increased levels of $\beta$-chemokines (active against R5 strains), and the reduced levels of neutralizing antibodies to which $\mathrm{X} 4$ tropic viruses are more sensitive [84] may trigger the phenotypic switch. The observation that many pathogens are potent inducers of HIV-suppressive $\beta$-chemokines suggests that opportunistic infections could contribute to the appearance of $\mathrm{X} 4$ strains during the symptomatic stage [85].

\section{HIV-suppressive $\beta$-chemokines}

The beta-chemokines MIP-1 $\alpha$ (CCL3), MIP-1 $\beta$ (CCL4), and RANTES (CCL5) are the natural ligands of CCR5. Two additional variants named CCL3L1 and CCL4L1, encoded by genes arising from the duplication of CCL3 and CCL4, respectively, have also been described [86]. The role of $\beta$ chemokines in HIV infection was first proposed in a seminal article in which the anti-HIV-1 effect of these molecules was reported just a few months before the discovery of CCR5 as co-receptor for HIV-1 [87]. Soon thereafter, several reports found inverse correlations between the levels of $\beta$-chemokines in plasma and the rate of disease progression [88,89]. Elevated levels of RANTES have also been associated with protection against HIV transmission in some EU cohorts [90]. Interestingly, no differences in the plasma levels of beta-chemokines have been observed in some EU cohorts. These individuals display normal levels of CCR5 on their CD4-positive T cells. However, CD4positive $\mathrm{T}$ cells from these EUs appear more sensitive to the HIV-1 inhibitory effect of $\beta$-chemokines, suggesting the existence of yet unknown mechanisms influencing the role of CCR5 in infection [91].

When bound to CCR5, $\beta$-chemokines induce internalization of the receptor, abrogating its ability to promote HIV1 infection [92]. The mechanisms governing inter-individual variations in $\beta$-chemokine expression are not completely understood. In support of a role for $\beta$-chemokines, SNPs in the MIP-1 $\alpha$ gene are found at elevated frequencies among EU individuals [93]. SNPs in the promoter regions of the RANTES gene have also been described and they could affect expression of RANTES. However, their role in disease progression remains controversial [94].

CCL3L1, also known as MIP-1 $1 \alpha \mathrm{P}$, is the more potent CCR5 agonist and the strongest inhibitor of infection by R5 HIV-1 strains [95]. Interestingly, the levels of CCL3L1 are determined, in part, by the number of tandem copies of the CCL3L1 gene, which varies from 2-10 among individuals, with highest copy numbers found in African populations [96]. When analyzed by itself, the number of CCL3L1 copies is not significantly associated with HIV susceptibility. However, significant trends are found when the number of copies is analyzed in the context of a specific population. Thus, people with higher number of copies than their ethnic background average are less susceptible to HIV-1 infection and progress slower to AIDS [96]. These findings underscore the important role of CCL3L1 in disease progression.

Another study has revealed a role for MIP-1 $\beta$ in HIV-1 pathogenesis [97]. This chemokine is encoded by two highly related genes (CCL4 and CCL4L1). Two polymorphisms of the CCL4L1 gene have been described (L1 and L2). Individuals homozygous for L2 display reduced levels of CCL4 transcripts when compared to homozygous for L1. A higher frequency of the L2 allele has been observed in a Spanish cohort of HIV-infected patients, as compared to healthy controls, suggesting that the levels of MIP-1 $\beta$ may influence HIV-1 susceptibility [97]. Polymorphisms in the RANTES gene have also been reported. Elevated levels of circulating RANTES are common in EU individuals and in HIV-seropositive patients displaying slow progression (reviewed in $[98,99])$. Two changes in the promoter $(-403 \mathrm{G} / \mathrm{A}$ and $-28 \mathrm{C} / \mathrm{G})$ appear to modulate in vitro transcription of RANTES. In vivo, the presence of the -403A and -28G haplotype has been associated with slower disease progression in Japanese and Thai cohorts $[100,101]$, and lower susceptibility to infection in a Chinese cohort [102]. A second study has analyzed only the 403A allele, confirming its protective role in HIV progression, but also describing it as a risk factor for HIV transmission [103]. Thus, the role of polymorphisms in the RANTES promoter remains controversial, with at least two other reports failing to confirm these associations in Spanish cohorts $[94,104]$. The reason for these discrepancies may be due to the quite different distribution frequencies of RANTES alleles across ethnic groups. Further complicating the study of RANTES polymorphisms, some alleles appear to mitigate the effect of others. Thus, the -28G allele, common in Asians, rare in Euopean-Americans (EA) and absent in Africans, mitigates the disease-accelerating effects of another RANTES variant, In1.1.C, which have been described in EAs [105]. This latter allelic variant 
by itself potently down-regulates RANTES transcription [106].

SDF-1 (also known as CXCL12) is the only known ligand of CXCR4 $[107,108]$. As with $\beta$-chemokines and CCR5, occupation of CXCR4 by SDF-1 induces internalization of the receptor [109]. Both CXCR4 and SDF-1 are essential during development, and knock out of either of these genes leads to lethal phenotypes in mice $[110,111]$. Not surprisingly, alleles leading to lack of expression of SDF-1 or CXCR4 have not been identified. Nevertheless, the role of of SDF-1 and CXCR4 in the adult life, recirculating leukocytes and hematopoietic precursors, may be less vital. A polymorphism in the noncoding region of SDF-1 has been reported (SDF1-3'A). In the homozygous form, the presence of an A at position 801 has been associated with slower progression to AIDS, as compared to heterozygous or wild-type homozygous. The biological basis for this association is not clear, since no differences in SDF-1 levels have been observed [112,113]. A number of reports have failed to confirm this association in other cohorts [114-117]. Thus, it is not clear whether the SDF1-3'A variant play a role disease progression.

Other chemokines such as MCP1 (CCL2), MCP3 (CCL7), and eotaxin (CCL11) bind CCR2 and CCR3, but not CCR5. Each of these chemokines have been associated with HIV pathogenesis. It has been suggested that they control migration of immune cells to sites of HIV-1 infection, thus contributing to virus propagation in vivo [118]. Table 1 summarizes the role of known variants of chemokine receptors and their ligands in HIV pathogenesis.

\section{DC-SIGN}

DC-SIGN is a mannose-binding, calcium-dependent lectin that has been involved in transmission of HIV-1 from dendritic cells (DC) to T lymphocytes, a phenomenom named "trans-enhancement" (reviewed in $[119,120]$ ). DC-SIGN is expressed on immature DCs and activated B lymphocytes. Trans-enhancement requires binding of HIV-1 particles to DC-SIGN via the high mannose glycans present in gp120. The mechanism of transfer of HIV-1 to $\mathrm{T}$ cells remains controversial. First, it was proposed that transfer requires internalization and transient storage of HIV-1 particles in subcellular compartments [121]. Recent evidence suggests that infection of DC cells is required for efficient transfer of HIV-1 to other cells [122].

DCs are thought to be among the first cells infected by HIV on the genital mucosa. Infected DCs migrate to lymph nodes where they transfer viruses to $\mathrm{T}$ cells. By infecting the very same cells implicated in protection against infection in mucosal tissue, HIV-1 utilizes DCs as Trojan horses that spread the virus to the lymph nodes. The role played by DCs in facilitating infection suggests a possible role for DC-SIGN variants and other C-type lectins in HIV-1 disease progression and transmission. A polymorphism in the DC-SIGN promoter at positions 336 has been identified. Individuals at risk of HIV carrying the $-336 \mathrm{C}$ allele are more susceptible to infection than persons with the $-336 \mathrm{~T}$ variant [123]. This association, however, has been observed for parenteral transmission of HIV-1, but not for mucosally acquired infection. Variants in the coding region of DC-SIGN and DC-SIGNR have also been identified. However, the importance of these alleles in protecting from HIV-1 infection has yet not been fully elucidated [124-126].

Langerin, also called CD207, is selectively expressed in Langerhans cells, which are spread over the mucosa through which HIV transmission occurs. Under some experimental conditions, Langerhans cells are infected with HIV-1 and transmit virions to T cells [127]. However, recent evidence suggests that Langerin, in contrast to DCSIGN, prevents HIV-1 transmission. HIV-1 particles captured by Langerin are internalized and degraded into Birbeck granules [128]. Thus, Langerhans cells appear to present a first barrier against infection. This study does not exclude the possibility that these cells transmit HIV-1 at high viral inocula [129]. The role of Langerin variants in HIV-1 transmission has not been studied, although a mutation in the langerin gene in a person deficient in Birbeck granules has been described [130].

In addition to DC SIGN, other C-type lectin receptors may also act as receptors for HIV-1: DC-SIGN-related (DCSIGNR), the mannose receptor (MR), and Langerin can also bind gp120 [120].

\section{Anti-HIV-I activity of human defensins}

Defensins are small antimicrobial and antiviral cysteinerich cationic peptides produced by leukocytes and epithelial cells. The role of defensins in innate immunity to fight bacterial, viral and fungal infections has long been known $[131,132]$ (reviewed in [133-135]). The first report on the anti-HIV-1 activity of defensins dates back to 1993 [136].

Mammalian defensins are classified into alpha-, beta-, and theta defensins, and differ in their size and distribution of disulfide bridges [135]. Alpha and $\beta$-defensins are peptides typically composed of 30-45 residues, and both display anti HIV-1 activity [135]. Theta-defensins are cyclic peptides composed of two alpha-like precursor peptides. Active theta-defensin products are found only in some non-human primates, and are typically composed of 16-18 residues [137]. Given their smaller size thetadefensins have been included in the family of minidefensins, which include molecules also found in other species such as horseshoe crabs and spiders [138]. In humans and chimpanzees theta-defensins are found only as inac- 
Table I: Chemokine and chemokine receptor variants modulating HIV transmission and pathogenesis

\begin{tabular}{|c|c|c|c|c|c|c|}
\hline Gene & Allele or factor & Mode & Effect & $\begin{array}{l}\text { Mechanism of } \\
\text { action }\end{array}$ & Frequency(I) $^{(1)}$ & References \\
\hline \multicolumn{7}{|c|}{$\begin{array}{l}\text { Chemokine } \\
\text { Receptor }\end{array}$} \\
\hline CCR5 & $\Delta 32$ & Recessive & $\begin{array}{l}\text { Resistance to } \\
\text { infection }\end{array}$ & $\begin{array}{l}\text { Truncated co- } \\
\text { receptor is not } \\
\text { expressed at the } \\
\text { cell surface. }\end{array}$ & $\begin{array}{l}\text { Caucasians (4- } \\
15 \%)\end{array}$ & $25,30,31$ \\
\hline CCR5 & $\Delta 32$ & Dominant & Delay AIDS & $\begin{array}{l}\text { Reduced co- } \\
\text { receptor } \\
\text { expression. }\end{array}$ & $\begin{array}{l}\text { Caucasians (4- } \\
15 \%)\end{array}$ & $38-41$ \\
\hline CCR5 & C20S & Dominant & $\begin{array}{l}\text { Prevent HIV } \\
\text { infection in the } \\
\text { presence of } \Delta 32\end{array}$ & $\begin{array}{l}\text { Very low co- } \\
\text { receptor } \\
\text { expression. Loss } \\
\text { of disulfide bridge, } \\
\text { improper folding? }\end{array}$ & Caucasians (0.3\%) & 49,51 \\
\hline CCR5 & A29S & Unknown (2) & Not evaluated & $\begin{array}{l}\text { Failure to bind } \\
\text { RANTES, MIP-I } \beta \\
\text { and MIP-I } \alpha\end{array}$ & Africans (I.5\%) & 49,51 \\
\hline CCR5 & R60S & Unknown (2) & Not evaluated & $\begin{array}{l}\text { Poor co-receptor } \\
\text { internalization }\end{array}$ & Africans (I.3\%) & 51 \\
\hline CCR5 & CIOIX & Dominant & $\begin{array}{l}\text { Prevent HIV } \\
\text { infection in the } \\
\text { presence of } \Delta 32\end{array}$ & $\begin{array}{l}\text { Truncated co- } \\
\text { receptor not } \\
\text { expressed at cell } \\
\text { surface }\end{array}$ & Africans (I.4\%) & $49,51,52$ \\
\hline CCR5 & GI06R & Unknown(2) & $\begin{array}{l}\text { HIV resistance/ } \\
\text { Delay AIDS? }\end{array}$ & $\begin{array}{l}\text { Very low co- } \\
\text { receptor } \\
\text { expression }\end{array}$ & Asians (I.4\%) & 50 \\
\hline CCR5 & CI78R & Unknown (2) & $\begin{array}{l}\text { HIV resistance/ } \\
\text { Delay AIDS? }\end{array}$ & $\begin{array}{l}\text { Very low co- } \\
\text { receptor } \\
\text { expression }\end{array}$ & Asians (0.5\%) & 49 \\
\hline CCR5 & $\mathrm{C} 269 \mathrm{~F}$ & Unknown(2) & $\begin{array}{l}\text { HIV resistance/ } \\
\text { Delay AIDS? }\end{array}$ & $\begin{array}{l}\text { Very low co- } \\
\text { receptor } \\
\text { expression. Loss } \\
\text { of disulfide bridge, } \\
\text { improper folding? }\end{array}$ & Asians (I.4\%) & 49,50 \\
\hline CCR5 & FS299 & Unknown(2) & $\begin{array}{l}\text { No effect on HIV } \\
\text { transmission }\end{array}$ & $\begin{array}{l}\text { Truncated co- } \\
\text { receptor, poorly } \\
\text { expressed }\end{array}$ & Asians (4\%) & 49 \\
\hline CCR5 & $\begin{array}{l}\text { PI (promoter } \\
\text { haplotype) }\end{array}$ & Recessive & Accelerate AIDS & $\begin{array}{l}\text { Increase CCR5 } \\
\text { expression? }\end{array}$ & Unknown & 53 \\
\hline CCR5 & $\begin{array}{l}\text { 59029-A/A } \\
\text { (promoter) }\end{array}$ & Recessive & Accelerate AIDS & $\begin{array}{l}\text { Increase CCR5 } \\
\text { expression }\end{array}$ & Caucasians (57\%) & 54 \\
\hline CCR2 & 641 & Dominant & $\begin{array}{l}\text { Delay AIDS in } \\
\text { some cohorts }\end{array}$ & $\begin{array}{l}\text { Influence CCR5 or } \\
\text { CXCR4 } \\
\text { expression? }\end{array}$ & General (10-20\%) & $62,64,66,67$ \\
\hline CX3CRI & I249/M280 & Recessive & Accelerate AIDS? & $\begin{array}{l}\text { Influence } \\
\text { recruitment of } \\
\text { immune cells? }\end{array}$ & $\begin{array}{l}\text { Caucasians (1249: } \\
\text { 26\%; M280: I4\%) }\end{array}$ & 69,71 \\
\hline
\end{tabular}

\section{Chemokine}

\begin{tabular}{|c|c|c|c|c|c|c|}
\hline $\begin{array}{l}\text { MIP-I } \alpha P \\
(C C L 3 L I)\end{array}$ & $\begin{array}{l}\text { Gene copy } \\
\text { number }\end{array}$ & & $\begin{array}{l}\text { Increase } \\
\text { susceptibility to } \\
\text { infection }\end{array}$ & $\begin{array}{l}\text { Copy number } \\
\text { correlates with } \\
\text { levels of CCR5 } \\
\text { agonist. Block HIV } \\
\text { entry }\end{array}$ & $\begin{array}{l}\text { Africans (5-7 } \\
\text { mean copy } \\
\text { number) }\end{array}$ & 96 \\
\hline MIP-I $\beta(C C L 4 L I)$ & L2 & Dominant & $\begin{array}{l}\text { Increase } \\
\text { susceptibility to } \\
\text { infection }\end{array}$ & $\begin{array}{l}\text { Reduced level of } \\
\text { MIP-I } \beta\end{array}$ & Caucasians (16\%) & 97 \\
\hline RANTES (CCL5) & $-403 \mathrm{~A}$ (promoter) & Dominant & Delay AIDS & $\begin{array}{l}\text { Up-regulate } \\
\text { RANTES } \\
\text { transcription }\end{array}$ & Asians (27\%) & $100-102$ \\
\hline
\end{tabular}


Table I: Chemokine and chemokine receptor variants modulating HIV transmission and pathogenesis (Continued)

\begin{tabular}{|c|c|c|c|c|c|c|}
\hline RANTES (CCL5) & -28G (promoter) & Dominant & Delay AIDS & $\begin{array}{l}\text { Up-regulate } \\
\text { RANTES } \\
\text { transcription }\end{array}$ & $\begin{array}{l}\text { Asians (8\%), rare } \\
\text { in Caucasians }\end{array}$ & $100-102$ \\
\hline RANTES (CCL5) & InI.IC (intronic) & Dominant & Accelerate AIDS & $\begin{array}{l}\text { Down-regulate } \\
\text { RANTES } \\
\text { transcription }\end{array}$ & General (14-17\%) & 106 \\
\hline SDF-I (CXCLI2) & 3'A & Recessive & Delay AIDS? & Unknown. & $\begin{array}{l}\text { Asians (25-35\%) } \\
\text { Oceanian (50- } \\
70 \%)\end{array}$ & 112,113 \\
\hline $\begin{array}{l}\text { MCPI/MCP3/ } \\
\text { Eotaxin }\end{array}$ & H7 haplotype & Dominant & $\begin{array}{l}\text { Decrease } \\
\text { susceptibility to } \\
\text { infection }\end{array}$ & $\begin{array}{l}\text { Unknown } \\
\text { immunomodulator } \\
\text { y effects }\end{array}$ & Caucasians (19\%) & 118 \\
\hline
\end{tabular}

(1) Allele frequency in populations in which the variant is more predominant. (2) No homozygous individuals have been identified

tive pseudogenes. These pseudogenes are transcribed into mRNAs, but they harbor premature stop codons that preclude expression of functional products. Interestingly, when the putative human ancestral gene for a human theta-defensin was reconstituted, it was found to display in vitro potent anti-HIV-1 activity against R5 and X4 strains [139]. The artificially reconstituted product was named human retrocyclin-1. This molecule displays lectin-like properties and binds to CD4 and gp120, thus preventing entry of HIV-1 into target cells [140].

So far six human $\alpha$-defensins (also known as human neutrophil peptides or HNP) have been identified. $\alpha$ defensins also bind CD4 and the viral envelope glycoprotein. Treatment of permissive cells with $\alpha$-defensins induces down-modulation of CD4 [141]. Additionally, in the absence of serum (e.g. at mucosal surfaces), $\alpha$ defensins may inactivate virion particles by a mechanism that includes membrane disruption [142]. These findings indicate that $\alpha$-defensins block HIV-1 entry at several steps, by directly inactivating virions and by blocking or eliminating the viral receptor from the cell surface. The mechanism of action of $\alpha$-defensins and their inhibition profile led researchers to suggest that these molecules could constitute the long-sought CD8-positive cell antiHIV factor (CAF) [143]. The existence of CAF was first suggested in 1986, as a soluble factor derived from CD8-positive cells in LTNP individuals with the ability to achieve durable immune responses controlling HIV-1 infection [144]. A report in 2002 suggested that based on specific antibody recognition, $\alpha$-defensins 1,2 , and 3 were responsible for the antiviral activity of the eluded CAF factor. Experiments demonstrated that CAF activity could be eliminated with anti- $\alpha$-defensins antibodies, and $\alpha$ defensins could be detected inside CD8-positive cells [143]. Later reports failed to confirm these results and found no evidence for the production of $\alpha$-defensins in CD8-positive cells, although CD8-positive cells may internalize $\alpha$-defensins. However, it is not clear whether the uptake of these molecules is needed for their function $[145,146]$. Beta-chemokines produced by CD8-positive cells may also contribute to the activity of CAF, which may no longer be ascribed to a single host factor. It is likely that CD8-positive cells express an unknown array of novel HIV-suppressive factors. Thus, the search to elucidate the CAF factor activities is still ongoing.

Six human $\beta$-defensins have been identified in epithelial cells, although genomic searches indicate that up to 28 different genes may be present in humans [147]. The mechanism of action of $\beta$-defensins shares some similarities with that of $\alpha$-defensins. They block viral entry of both X4- and R5-tropic HIV-1 strains, although their effect is more potent with T-tropic isolates. Beta-defensins 2 and 3 achieve their inhibitory effect in part by direct inactivation of viral particles, and also by down-modulation of CXCR4, but not CCR5, on T cells [148]. This latter mechanism, however, has not been confirmed by others [149]. Interestingly, HIV-1 induces expression of human $\beta$ defensins 2 and 3, but not 1, the latter of which displays poor antiviral activity. Induction of these defensins occurs by a mechanism that does not require viral replication $[148,150,151]$. Recent findings suggest that $\beta$-defensin 2 may mediate its effect via CCR6. Beta-defensin 2 binds CCR6, and its inhibitory effect is abrogated after treatment of cells with anti-CCR6 antibodies. In agreement with this, MIP-3- $\alpha$ (also known as CCL20), the cognate ligand for CCR6, blocks HIV-1 infection in a manner similar to $\beta$-defensin 2 [152]. CCR6 is not a co-receptor for HIV-1, but is expressed in CD4+CD45RO+CCR5+ lymphocytes and dendritic cells, where it may play an important role governing the movement of immune cells to mucosal surfaces, the first tissues encountered by HIV during sexual transmission. Thus, $\beta$-defensins may also control HIV-1 replication by modulating the immune system. The mechanisms of defense against HIV infection mediated by $\alpha-, \beta-$, and $\theta$-defensins are summarized in Table 2 .

The demonstrated antiviral activity of defensins have encouraged the search for polymorphisms influencing HIV-1 infection and disease progression. Both, $\alpha-$, and $\beta$ defensins have been found in human breast milk, suggest- 
Table 2: Anti-HIV activity of human defensins

\begin{tabular}{|c|c|c|c|c|}
\hline Defensins & Regulation & Cell Source & Mechanisms & References \\
\hline \multicolumn{5}{|l|}{$\alpha$-Defensins } \\
\hline HNPI, HNP2, and HNP3 & $\begin{array}{l}\text { Constitutive HPN2 may be } \\
\text { the product of proteolytic } \\
\text { processing of HNPI/HPN3 }\end{array}$ & $\begin{array}{l}\text { Neutrophils and } \\
\text { promyelocytes }\end{array}$ & $\begin{array}{l}\text { - CD4 down-modulation } \\
\text { - Viral membrane disruption } \\
\text { and binding to CD4 and } \\
\text { gPI } 20 \text { (in absence of serum) } \\
\text { - Upregulation of CC- } \\
\text { chemokines in macrophages } \\
\text { - Block of nuclear transport } \\
\text { (by HNPI) }\end{array}$ & $131,143,146$ \\
\hline HNP4 & Constitutive & Neutrophils & $\begin{array}{l}\text { - Unknown (lectin- } \\
\text { independent mechanism) }\end{array}$ & 135 \\
\hline \multicolumn{5}{|l|}{$\beta$-Defensins } \\
\hline $\mathrm{HBD} 2$ and $\mathrm{HBD} 3$ & $\begin{array}{l}\text { Inducible by HIV, } \\
\text { opportunistic infections, and } \\
\text { pro-inflammatory cytokines } \\
\text { (TNF, IL-IB) }\end{array}$ & $\begin{array}{l}\text { Epithelial cells, monocytes, } \\
\text { monocytes-derived DCs, } \\
\text { macrophages, and } \\
\text { keratinocytes }\end{array}$ & $\begin{array}{l}\text { - Viral membrane disruption } \\
\text { (absence of serum) } \\
\text { - CXCR4 down-modulation } \\
\text { - CCR6-mediated } \\
\text { chemotactic effects }\end{array}$ & $|48-15|$ \\
\hline \multicolumn{5}{|l|}{$\theta$-Defensins } \\
\hline Retrocyclins (RTDI, RTD2) & $\begin{array}{l}\text { Synthesis blocked in humans } \\
\text { by premature termination } \\
\text { codon }\end{array}$ & $\begin{array}{l}\text { RNA transcripts, not } \\
\text { protein, expressed in } \\
\text { bone marrow }\end{array}$ & $\begin{array}{l}\text { - Prevent HIV entry by } \\
\text { binding to CD4 and gP } 20\end{array}$ & $\mid 38-140$ \\
\hline
\end{tabular}

ing that they could play a role in protecting infants from infection $[153,154]$. One study has associated the amount of $\alpha$-defensins in breast milk with protection against intrapartum and postnatal transmission of HIV-1 [155]. SNPs in the $5^{\prime}$-untranslated region of the human $\beta$-defensin 1 gene (DEFB1) have been associated with HIV-1 infection in an Italian pediatric cohort. The presence of a $\mathrm{C} / \mathrm{C}$ allele at position - 44 in HIV-1 infected mothers and their children is associated with higher risk of maternal-fetal transmission $[156,157]$. These results have been confirmed by the same group in another cohort of Brazilian children [158]. However, studies with HIV-1 infected adults are still missing. Further highlighting the role of human defensins in HIV pathogenesis, elevated levels of $\alpha$ defensins have been reported in EU individuals and HIVinfected women, as compared to healthy controls [159]. Interestingly, human genes for both $\alpha$-defensins (DEFA1 and DEFA3), and $\beta$-defensins (DEFB4, DEFB103, and DEFB104) are known to be polymorphic in copy number [160-162]. Transcription of these genes correlates with copy number, and it is tempting to speculate that, as demonstrated for the CCL3L1 and CCL4L1 chemokines, polymorphisms in the copy number of defensin genes may modulate HIV-1 susceptibility and disease progression.

\section{Host factors modulating early post-entry events of HIV-I replication Cyclophilin A and TRIM5 $\alpha$}

Studies in the early ' 80 s identified cyclophilin A (CypA) as a cytosolic protein binding to the immunosuppressant molecule cyclosporin A [163]. Subsequent studies identified an anti-HIV activity of cyclosporin A $[164,165]$, although its mechanism of action was not elucidated at that time. The role of CypA in HIV-1 replication was investigated in detail after discovering its HIV-1 capsid (CA) binding properties in a yeast two-hybrid screen [166]. As a result of this interaction CypA is incorporated into virion particles [167-169]. After years of studies the mechanism of action of CypA has just begun to be unraveled. HIV-1 has a limited host range that appears to be explained in part by the existence of saturable inhibitory factors that block virus replication at early steps, before reverse transcription occurs [170-172]. CypA promotes HIV-1 infectivity in target cells by a mechanism that does not require CypA incorporation into virions $[173,174]$. The exact mechanism of action remains an enigma. CypA appears to modulate the action of other restriction factor(s), perhaps by altering CA conformation in a manner that makes it less sensitive to their inhibitory effect (reviewed in [175]). The nature of the proposed conformational change may relate to the cis-trans isomerization 
of peptidyl-prolyl bonds mediated by CypA. However, the significance of this activity has not been conclusively demonstrated [176]. Interestingly, cyclophilins may constitute modulators of the innate immune response in other eukaryotic systems. Recently, an innate mechanism of defense against Pseudomonas syringae infection has been described in Arabidopsis. Upon infection, a plant cyclophilin activates a bacterial protease, which then triggers a cascade of events that activates a plant's defense response [177]. Thus, cyclophilins may represent evolutionarily conserved mechanisms of innate defense.

Several SNPs have been identified in the human CypA gene (PP1A). Their associations with HIV-1 infection and disease progression in vivo have not been studied to date. However, one group has used an ex vivo approach to evaluate polymorphisms in PP1A. In this strategy, CD4 T cells were purified from healthy donors and challenged in vitro with HIV-1. The extent of viral replication was correlated with specific alleles, and when in vivo data is available, correlations with disease progression in a cohort of HIV-1 infected individuals were sought. Following this approach a polymorphism in the PP1A promoter (1650A/G) was associated with lower ex vivo virus replication in cells derived from PP1A homozygous individuals (AA), and slower disease progression in vivo [12]. The ex vivo replication profile in cells carrying alleles previously associated with slow progression (CCR5 $\Delta 32$ and CCR264I) or rapid disease progression (RANTES In1.1C) followed the expected trend, confirming the validity of this ex vivo approach to identify relevant alleles. Nevertheless, validation studies with other cohorts will be needed to define the role of CypA variants in HIV-1 pathogenesis.

Another cellular factor implicated in early steps of HIV-1 replication is TRIM $5 \alpha$. This protein was identified from a rhesus macaque library screened for simian factors restricting HIV-1 replication upon transfer into otherwise permissive human cells [178]. Early studies suggested that the action of TRIM $5 \alpha$ and CypA were somehow related, and as mentioned above, it was suggested that CypA protects CA from the deleterious effects of human TRIM $5 \alpha$ [175]. TRIM5 $\alpha$ also binds HIV-1 CA, though apparently in a CypA-independent manner [179-181]. An alternative model proposes that common restriction factors may be shared in the cascade of events that leads to inhibition of HIV-1 replication by TRIM $5 \alpha$, and promotion of infectivity by CypA [175].

Unlike simian forms, the human ortholog of TRIM $5 \alpha$ appears to only modestly inhibit HIV-1 replication. This has led to the hypothesis that polymorphisms in the human TRIM5 $\alpha$ gene might result in increased restriction and modulate HIV-1 infection. One recent report has identified a TRIM5 $\alpha$ haplotype (hap 9) containing a non- synonymous SNP at position 136 (R136Q) that occurs with higher frequency among HIV-infected subjects than in exposed seronegative individuals [182]. None of the individual SNPs found in this haplotype influenced HIV transmission, suggesting that the genetic sequence responsible for the observed phenotype is in linkage disequilibrium with this haplotype, lying in TRIM5 or one of the TRIM genes adjacent to it. Another study evaluated the 136Q allele and found the frequency of this allele elevated in uninfected African-Americans, as compared to HIV-1 infected subjects. However, this correlation was not observed in individuals of European descent. In agreement with a role for TRIM5 $\alpha$, the 136Q variant exhibited slightly stronger inhibitory activity than the 136R counterpart [183]. The same study reported the identification of two additional non-coding SNPs present in one TRIM $5 \alpha$ haplotype that is found in HIV-1 infected patients at higher frequencies than in uninfected individuals. The above studies suggest that polymorphisms in TRIM $5 \alpha$ may influence susceptibility to HIV-1 infection. Only one study has evaluated the role of common TRIM $5 \alpha$ variants on disease progression. The authors analyzed a cohort of 979 HIV-infected patients and found only modest associations with the rate of CD4-positive $\mathrm{T}$ cell decline before the onset of treatment [184]. The viral determinants for sensitivity to inhibition by TRIM $5 \alpha$ lie in the viral CA region. In vitro, mutations in HIV-1 CA overcome the restriction of HIV-1 to replicate in simian cells. A study by the Schuitemaker group has evaluated the presence of TRIM5 $\alpha$ escape mutants in HIV-1 infected individuals, as an indicator of TRIM $5 \alpha$-mediated inhibition. Interestingly, CA escape mutants emerging late in the infection process could be found in $14 \%$ of the infected patients (N.A. Kootstra and H. Shuitemaker, personal communication). These findings suggest the existence of selective pressure on the virus to avoid TRIM $5 \alpha$-mediated restriction.

\section{The innate immune response mediated by $A P O B E C 3 G$}

Host cells are endowed with another mechanism to halt HIV-1 infection before integration occurs. The human apolipoprotein B mRNA-editing enzyme-catalytic polypeptide-like-3G (APOBEC3G), formerly known as CEM15, is an endogenous inhibitor of HIV-1 replication [185-187]. In the absence of the viral protein Vif, APOBEC3G is incorporated into HIV-1 particles in the producer cell, and during reverse transcription deaminates cytosine bases to uracil in the negative-sense singlestranded DNA, resulting in G to A hypermutations in the complementary, positive sense DNA strand. This hypermutation leaves the viral cDNA vulnerable to degradation by nucleases. Those cDNAs that manage to integrate into the host chromosomes carry multiple mutations that likely result in aberrant viral products [188-190]. Recent reports appear to suggest that APOBEC3G also exerts anti- 
viral activities through mechanisms independent of its cytidine deaminase activity $[191,192]$. APOBEC3G can be found in cells in two different forms of low and high molecular-mass (LMM and HMM, respectively). APOBEC3G in LMM form is enzymatically active and restricts HIV-1 infection. The HMM form is a catalytically inactive ribonucleoprotein complex that appears to protect against mobilization of endogenous cellular retroelements such as Alu and hY [193-195]. Endogenous retroelements can influence transcription of adjacent genes and induce genetic disease in humans by insertional inactivation [196-198]. This APOBEC3G-induced mechanism of restriction of Alu and hY mobilization is mediated by sequestration of the RNA retroelements into HMM complexes, which are kept away from the L1dependent retrotransposition machinery [193]. APOBEC3G and related deaminases may also protect against other retroviruses and hepatitis B virus, which also relies on a reverse transcription step to complete its life cycle $[186,191]$.

The Vif protein binds APOBEC3G in virus producer cells and targets it for degradation in the proteasome, thus preventing APOBEC3G incorporation into virions [199-201]. To induce APOBEC3G degradation Vif binds the cellular proteins Cul5, elonginB, elonginC and Rbx1, to form a cullin5-based E3 ubiquitin ligase complex that leads to polyubiquitination and ultimately to proteasomal degradation of APOBEC3G and APOBEC3F, which also displays anti-HIV activity $[200,202]$.

The importance of the APOBEC3G-mediated innate response against HIV-1 is underscored by the existence of both APOBEC3G and Vif genetic variants influencing disease progression. Studies with LTNP have revealed an association between low viral load and a serine residue at position 132 of Vif. When tested in vitro, HIV-1 carrying Ser132 displayed a five-fold decrease in replication in $\mathrm{PBMC}$, as compared to virus containing the wild type allele (Arg) at the same position [203]. Another study revealed the presence of a two-amino-acid insertion in the Vif protein of a mother's virus and her child's, both LTNP. This amino acid insertion results in an aberrant Vif protein that severely impairs replication when expressed in a recombinant HIV-1 [204]. Furthermore, Vif-defective proteins have been isolated from strains from other LTNP individuals [205]. The reason why some of these LTNP Vif variants do not revert to encode a functional product is not understood. It is possible that Vif plays other roles in viral replication that constrain its ability to mutate. Alternatively, the genetic background of these LTNPs may have weakened the virus' ability to replicate and mutate in these subjects.
With regards to APOBEC3G, it is plausible that genetic variants with altered inhibitory activity or partially resistant to Vif might alter the course of HIV-1 disease. A variant of APOBEC3G common in African-Americans has been identified, which contains a non-synonymous substitution. This allele carries Arg instead of His at position 186 (186R) and is strongly associated with faster decline of CD4 T cells and accelerated progression to AIDS [206]. This variant, however, appears to have the same in vitro inhibitory activity than the common $186 \mathrm{H}$ allele. An extensive analysis of a French cohort failed to identify significant associations between 29 APOBEC3G polymorphisms and disease progression, although discrepancies with previous studies may be explained by the different variables used to analyze disease progression [207]. Another study identified an APOBEC3G variant (C40693T) in a cohort of EU Caucasians subjects. This allele was found to be strongly associated with increased risk of infection [208]. A recent report revealed an inverse correlation between APOBEC3G mRNA levels and viral load in infected individuals, with the highest APOBEC3G levels observed in LTNP patients [209]. However, no associations with specific variants in the APOBEC3G gene have been identified in these individuals. The controversy over APOBEC3G variants, and the lack of a potential mechanism to explain their phenotypes warrants the need for additional studies.

A recent study has evaluated polymorphisms in the CUL5 gene encoding the Cullin 5 protein. Haplotypes encompassing 12 SNPs were clustered into two different groups that segregated with different profiles of $\mathrm{CD} 4 \mathrm{~T}$ cell decline rates and viral load [210]. One individual SNP (SNP6 A/G) appears responsible for the rapid CD4 T cell depletion and progression to AIDS. This correlation was observed in African-Americans, but not found in European-American and Asian populations. Interestingly, a significant additive effect was observed between some of the SNPs found in CUL5 and the APOBEC3G-186H allele. This study highlights the role of Cullin 5 in HIV-1 pathogenesis. Additional studies will be needed to understand the roles of CUL5 variants. Table 3 summarizes the effect on HIV infection and progression to AIDS of known genetic variants of human genes participating in postentry steps of the virus life cycle.

\section{Cellular factors modulating late steps of HIV-I replication}

The final steps of HIV-1 replication involve viral assembly and the release of new progeny. HIV-1 encodes the viral protein $\mathrm{U}(\mathrm{Vpu})$, which facilitates viral release from infected cells. Vpu appears to overcome the inhibitory effect of cellular factor(s) blocking viral budding $[211,212]$. The identity of this factor remains elusive. Recent evidence suggests that this factor may redirect HIV- 
Table 3: Human genes modulating HIV pathogenesis by influencing post-entry steps of the viral life cycle

\begin{tabular}{|c|c|c|c|c|c|c|}
\hline Gene & Allele or factor & Mode & Effect & $\begin{array}{l}\text { Mechanism of } \\
\text { action }\end{array}$ & Frequency(I) & References \\
\hline CypA (PPIA) & $1650 \mathrm{G}$ & Recessive & Delay AIDS & Unknown & Unknown & 12 \\
\hline $\operatorname{TRIM} 5 \alpha$ & Haplotype 9 & & $\begin{array}{l}\text { Increase HIV } \\
\text { transmission }\end{array}$ & Unknown & Caucasians (I\%) & 182 \\
\hline TRIM5 $\alpha$ & $136 Q$ & Dominant & $\begin{array}{l}\text { Protect against } \\
\text { HIV infection }\end{array}$ & $\begin{array}{l}\text { I36Q variant } \\
\text { displays stronger } \\
\text { anti-HIV activity }\end{array}$ & $\begin{array}{l}\text { African Americans } \\
(20 \%)\end{array}$ & 183 \\
\hline TRIM5 $\alpha$ & $43 Y$ & Dominant & $\begin{array}{l}\text { Protect against } \\
\text { HIV infection }\end{array}$ & Unknown & $\begin{array}{l}\text { African Americans } \\
(6.5 \%)\end{array}$ & 183 \\
\hline APOBEC3G & I86R & Recessive & Accelerate AIDS & Unknown & $\begin{array}{l}\text { African Americans } \\
(36.7 \%)\end{array}$ & 206 \\
\hline APOBEC3G & C40693T & Unknown & $\begin{array}{l}\text { Increase HIV } \\
\text { transmission }\end{array}$ & $\begin{array}{l}\text { Unknown (variant } \\
\text { found in intronic } \\
\text { region) }\end{array}$ & Caucasians $(<1 \%)$ & 208 \\
\hline Cullin5 & SNP6 A/G & $\begin{array}{l}\text { Dominant } \\
\text { (additive) }\end{array}$ & $\begin{array}{l}\text { Accelerated CD4 } \\
\text { T cell depletion } \\
\text { and AIDS } \\
\text { progression }\end{array}$ & $\begin{array}{l}\text { Unknown (the } \\
\text { SNP6 G product } \\
\text { displays stronger } \\
\text { binding to nuclear } \\
\text { proteins }\end{array}$ & Africans $(5 \%)^{(2)}$ & 210 \\
\hline TSGIOI & $-183 C$ & Dominant & $\begin{array}{l}\text { Accelerated CD4 } \\
\text { T cell decline }\end{array}$ & $\begin{array}{l}\text { Increase virus } \\
\text { budding? } \\
\text { (paradoxically the } \\
\text { - I83C variant } \\
\text { reduces } \\
\text { replication in ex- } \\
\text { vivo systems) }\end{array}$ & Caucasians (17\%) & 12,229 \\
\hline
\end{tabular}

(1) Allele frequency in populations in which the variant is more predominant. (2) Higher allele frequencies are observed in European Americans (I0\%) and Chinese (20\%), however the correlation is not observed in these populations.

1 particles to an endocytic route, a phenomenon that is overcome by expression of Vpu [212]. Some studies have suggested that Vpu may act by counteracting the potassium channel TASK-1, which interferes with the release of retroviruses by unknown mechanisms $[213,214]$. $\mathrm{Vpu}$ is also known to interact with $\beta$ TRCP, a component of a cullin1-based E3 ubiquitin ligase. Interaction between Vpu and $\beta$ TRCP targets CD4 for proteasomal degradation, contributing to virus-induced down-modulation of CD4. By binding to $\beta T R C P$, Vpu also inhibits the $\beta$ TRCPdependent degradation of IкB, which results in suppression of NF- $\mathrm{KB}$ and induction of apoptosis in infected cells $[215,216]$. Therefore, it is plausible that the levels of these proteins or polymorphisms in cellular genes implicated in Vpu function modulate HIV-1 susceptibility and disease progression in vivo.

The cellular determinants responsible for assembly and release of HIV-1 have been extensively documented in the last five years. TSG101 (tumor susceptibility gene 101) encodes a host cellular protein required for HIV-1 budding. The PTAP "late domain" found in the P6 product of HIV-1 Gag recruits TSG101 (also known as VPS23) to facilitate virus budding [217-219]. In uninfected cells TSG101 functions in the biogenesis of the multivesicular body (MVB), which is required for the sorting of mono- ubiquitinated transmembrane proteins into internal vesicles. HIV-1 P6, through its interaction with TSG101, usurps the cellular machinery to promote viral budding at the plasma membrane in T cells and macrophages [220$222]$ (reviewed in $[223,224]$ ). TSG101 is a component of the ESCRT-1 complex (endosomal sorting complex required for transport), and is known to bind multiple components of the MVB machinery (VPS28, VPS37, AIP1, Hrs, TOM1L1, EAP30, EAP45, and GGA proteins). At least eleven different human proteins have been shown to modulate HIV-1 budding (TSG101, VPS28, VPS37C, CHMP2A, CHMP3, CHMP4B, CHMP4C, VPS4A, VPS4B, AIP1, and Tal), and it is likely that many other components of the MVB pathway participate in this step of the viral cycle [223-228].

A few studies have evaluated polymorphisms in TSG101. One study utilized an ex-vivo/in vivo approach to evaluate a SNP in the noncoding region of the tsg101 gene (position -183). The presence of $\mathrm{C}$ at this position (instead of $\mathrm{T}$ ) results in a dominant effect that significantly reduces replication of HIV-1 in vitro [12]. Paradoxically, the same allele leads to faster disease progression (measured as CD4 cell count decline). Thus the role of this variant in HIV pathogenesis remains unclear $[12,229]$. 
It has long been known that interferon- $\alpha$, a key component of the innate response against some viral infections, interferes with HIV-1 particle release, however its mechanism of action has remained unknown until recently $[230,231]$. The interferon-induced ubiquitin-like protein ISG15 appears to be a critical component of the interferon- $\alpha$ antiviral response. ISG15 inhibits ubiquitination of TSG101 and the late HIV-1 Gag domain, inhibiting the P6-TSG101 interaction required for viral budding [232].

Another cellular factor regulating late steps of the viral cycle is HP68 (also known as ABCE1 and RNase L inhibitor). HP68 appears to be critical in the assembly of the HIV-1 capsid proteins. HP68 interacts with the NC domain of Gag, and as proteolytic processing of the Gag polypeptide occurs, HP68 is released from these complexes and viral particles acquire their mature conformation [233-235]. The role of HP68 in HIV pathogenesis in vivo has not yet been evaluated.

The matrix region of HIV-1 Gag binds the delta subunit of the adaptor protein complex 3 (AP-3). This interaction appears to play an important role in particle assembly [236]. Although its role in HIV pathogenesis has not been studied, mutations in ADTB3A, which codes for the beta3A subunit of AP-3, have been characterized in individuals with a rare form of Hermansky-Pudlak syndrome [237]. These individuals present defects in the vesicular trafficking pathways leading to formation of the melanosomal compartment, and are characterized by the presence of oculocutaneous albinism.

\section{Cellular factors incorporated into HIV-I particles}

Many cellular proteins known to play important roles in HIV-1 pathogenesis are incorporated into virions. For instance, CypA, APOBEC3G, TSG101, and VPS28, which are required at different steps of the viral cycle, are encapsidated into virions $[167,189,217,238]$. Most cellular proteins are incorporated into viral membranes in a passive manner if they associate with areas of the cell membrane through which the virus buds (reviewed in [239]). However, some proteins are specifically incorporated into viral membranes through interaction with viral products. Specific incorporation of cellular proteins inside virions or into viral membranes has generally been seen as suggestive of a functional role in the HIV-1 life cycle. Thus, it is expected that many other proteins known to associate with virions play a role in HIV-1 transmission and disease progression. Among these potential candidates are the integral membrane-spanning intracellular adhesion molecule 1 (ICAM-1). ICAM-1 expression drastically enhances HIV-1 infectivity, and makes virions more resistant to neutralization with gp120-specific antibodies or sera from HIV-infected patients [240-245]. Enhancement of infectivity can be blocked with anti-ICAM-1 mAbs, and is augmented in cells expressing higher levels of LFA-1, the ICAM-1 receptor. These findings suggest that HIV-1 may use an ICAM-1/LFA-1 dependent route to promote cellular entry and escape the humoral immune responses targeting the viral envelope protein. The interaction between ICAM-1 and LFA-1 may also play an important role in infection of CD4-positive memory $\mathrm{T}$ cells, which are considered a latent reservoir of the virus [246]. Polymorphisms in the ICAM-1 gene have been associated with susceptibility to a range of degenerative and inflammatory diseases. However their role in HIV pathogenesis has not been evaluated [247].

Specific incorporation into HIV-1 virions of host-derived HLA-DR, $\beta 2$-microglobulin and class I MHC molecules has long been known $[248,249]$. However, the physiological relevance of these associations is poorly understood. Several explanations have been suggested. Interestingly, immunization with HLA-DR and class I MHC proteins confer protection against SIV infection, probably by generating class-I and class-II-specific antibodies [250,251]. Additionally, incorporation of HLA-DR, one of the most abundant cellular proteins, into viral membranes, renders virions capable of stimulating purified $\mathrm{T}$ lymphocytes in the presence of the staphylococcal enterotoxin A superantigen [252]. Evidence that these mechanisms may influence HIV-1 pathogenesis is still missing, and these studies should be interpreted with caution. It has also been suggested that virion incorporation of MHC molecules could enhance virus infectivity [239].

Other proteins specifically incorporated into lentivirus capsids are hsp70, Ini1/SNF5, and the lysyl-tRNA synthetase. Different roles in the viral life cycle have been ascribed to these proteins. Hsp70 enhances the infectivity of HIV-1 [253], whereas Ini1/SNF5 appears to modulate virus yield and infectivity [254]. Lysyl-tRNA synthetase may participate in the recruitment of tRNALys to prime viral DNA synthesis [255-257]. The role of these proteins in HIV-1 pathogenesis in vivo has not been addressed.

\section{Host proteins modulating HIV-I envelope incorporation}

There is mounting evidence that the levels of envelope in HIV-1 particles are finely modulated and could play an important role in viral pathogenesis. Recent studies have changed the common view of the HIV-1 virion. Initially, it was believed that, like in other enveloped viruses, HIV1 viral membranes were abundant in envelope proteins. It is now known that the relative density of envelope spikes in HIV-1 virions is surprisingly low. Compared to influenza, which contains 200-300 spikes per particle, it is estimated that HIV-1 virions incorporate only 4 to 7 spikes per particle [258]. The reason for maintaining envelope levels to a minimum is unknown, though it may be 
related to the need to evade the antibody neutralizing response directed against the viral envelope.

In HIV-1, specific signal sequences in the cytoplasmic and membrane domain of gp 41 modulate expression of envelope at the cell surface. Interactions between the cytoplasmic domain of gp41 and the viral matrix protein modulates envelope incorporation by a mechanism that requires the cellular protein TIP47 [259-264]. The CD4 receptor, which plays an essential role allowing viral entry, inhibits envelope incorporation late in the viral cycle (reviewed in [265]). Excessive amounts of CD4 in virus-producer cells interfere with envelope transport to the cell surface, preventing its incorporation into viral membranes $[266,267]$. Additionally, CD4, which is normally excluded from viral membranes, is then incorporated into HIV-1, interfering with the ability of envelope to bind CD4 in target cells. To overcome the inhibitory effects of CD4, HIV-1 utilizes three viral products, Nef, $\mathrm{Vpu}$, and Envelope, to ensure CD4 is removed after its function in viral entry has been performed $[265,268,269]$. The importance of CD4 down-modulation in HIV-1 replication has been highlighted in recent studies. Nef-mediated CD4 down-regulation correlates with the ability of HIV-1 to replicate in blood-derived primary lymphocytes and human lymphoid tissue [270-272]. Other studies have evaluated the Nef-dependent CD4 down-modulation activity through different stages of disease. Nef alleles isolated from late symptomatic stages are more potent CD4 down-modulators than alleles isolated from the chronic asymptomatic stage $[273,274]$. This enhanced activity translates in faster HIV-1 replicative properties in vitro, and presumably in enhanced pathogenicity in vivo. Many other studies have revealed the existence of mutations or deletions in nef genes isolated from LTNP patients. In some instances, these changes have been associated with diminished CD4 down-modulation activity [275-278].

No enzymatic activities have been associated to HIV-1 $\mathrm{Nef}$, and it is widely accepted that this viral product exerts its CD4 down-modulation activity by binding to host proteins. Nef is known to interact with more than 25 cellular proteins. The physiological relevance of these interactions, however, has not always been evaluated [279]. Despite the potential role of cellular partners involved in Nef activities, to date no studies evaluating their influence in HIV-1 pathogenesis have been performed.

\section{Host factors modulating the innate immune response against HIV-I infection}

The cytokine system and its role in immunity against HIV-I Cytokines play an important role in controlling the homeostasis of the immune system and the response against pathogens. The role of IL-1, IL-2, IL-4, IL-6, IL-10, IL-16 and IL-18 in HIV-1 disease progression has been amply documented, as have IFN- $\alpha$, IFN- $\beta$, TNF- $\alpha$, and TNF- $\beta$.

With regards to HIV infection, cytokines can be grouped into HIV-inducing (TNF- $\alpha$, TNF- $\beta$, IL-1, and IL-6), and HIV-suppressive (IFN- $\alpha$, IFN- $\beta$, and IL-16). IFN-gamma and IL-4 display both stimulatory and anti-HIV effects [280]. IL-1 $\alpha$ and IL-1 $\beta$ are co-stimulatory cytokines for T helper cells and promote maturation and clonal expansion of B cells [281]. The role of the IL-1-dependent inflammatory response has been highlighted by the identification of polymorphisms of the IL-1 receptor gene (IL1R $\alpha$ ). The SNP IL1R $\alpha-2134$ has been found at higher frequency in a French cohort of slow progressors [282]. IL2 , a potent inducer of proliferation of antigen-primed $\mathrm{T}$ lymphocytes, also plays an essential role in immune regulation. Deficiency in IL-2 production is one of the first immunologic defects described in HIV-1 infected individuals [283]. Polymorphisms in the IL-2 gene have been extensively analyzed in a study of HIV-seropositive African-Americans [284]. A SNP deletion in a noncoding region of IL-2 (IL2+3896) was associated with disease progression in homozygotic individuals.

IL-4 is a Th2 cytokine with co-stimulatory activity for T and B cells. It has opposite effects on the HIV-1 co-receptors, upregulating CCR5 and down-modulating CXCR4, although it is not clear whether modulation of the HIV-1 co-receptors is sufficient to influence viral entry. Other IL4-dependent inhibitory effects in HIV-1 replication have been documented, although these appear to be celldependent and mostly affect X4-tropic strains. An IL-4 SNP (589T) known to influence transcription of the cytokine has been associated with progression to AIDS in some but not all studied cohorts [285,286]. Genetic studies of the IL-4 receptor alpha chain gene have also found significant associations with disease progression and susceptibility to HIV-1 infection, although this latter phenotype appears to depend on the route of transmission [287].

IL-16, a ligand for CD4, is a multifunctional cytokine. IL16 induces expression of class II MHC and displays chemotactic properties on CD4-positive T cells and monocytes. IL-16 binds CD 4 at an epitope distinct from from the HIV1 envelope binding site. The cytokine inhibits HIV-1 transcription in T lymphocytes and monocytic cells $[288,289]$. Several studies have described the influence of IL-16 in HIV-1 infection. The protective role of IL-16 appears to occur at two different levels. First, IL-16 suppresses HIV-1 replication. Second, IL-16 facilitates immune reconstitution by enhancing expression of IL-2 receptors and making T cells responsive to IL-2 [290]. Interestingly, T cell clones from LTNP individuals express higher levels of IL16 than cells from AIDS patients [291]. Other clinical 
studies have found decreased levels of IL-16 as disease progression advances [292,293]. Polymorphisms in the IL-16 gene have been identified, but no associations with HIV/AIDS have been reported to date [294].

IL-18 is a pro-inflammatory cytokine mostly secreted by activated macrophages. IL-18 is known to play an important role in responses against viruses and intracellular pathogens. IL-18 induces IFN- $\gamma$ production in T cells and enhances NK cytotoxic activity. Increased levels of IL-18 have been found in late stage HIV-1 patients, and plasma levels of this cytokine correlate with viral load, constituting an excellent marker for disease progression [295-297]. Several polymorphisms in the IL-18 gene are known, and at least one SNP (IL18 C607A) has been associated with increased risk of infection in a pediatric cohort $[298,299]$.

Proteins of the interferon family play essential roles in the innate response against viruses, including HIV-1. Type 1 interferons (IFN- $\alpha$ and IFN- $\beta$ ) induce expression of protein kinase R (PKR), which blocks protein synthesis in virus-infected cells. IFN- $\alpha / \beta$ also enhance lytic activity of NK cells, making them very effective in killing virallyinfected cells [300]. Polymorphisms in the IFN- $\alpha$ receptor 1 (IFNAR1) have been associated with disease progression and susceptibility to HIV-1 infection [301].

\section{Toll-like receptors}

Another key family of proteins participating in the innate immune response against pathogens is the Toll-like-receptors (TLR) family. During HIV infection, TLRs may play an important role in modulating the extent of viral replication (reviewed in [302,303]). There is mounting evidence that in addition to direct activation of TLRs by HIV, indirect activation mediated by opportunistic pathogens may influence the outcome of disease [304,305]. Signals mediated by pathogens can activate HIV transcription in trans, via the production of proinflammatory cytokines such as TNF- $\alpha$, IL- 1 , or in cis, directly inducing expression of cellular factors activating the viral LTR (NF- $\mathrm{KB}$ and AP-1) [302].

Eleven TLR members have been identified so far in humans [306]. TLRs recognize specific motifs expressed by pathogens such as lipid moieties, protein motifs, and nucleotide sequences. The first piece of evidence suggesting a role for TLRs in HIV-1 pathogenesis dates back to 1990, when it was shown that bacterial LPS activates the viral LTR, a process later found to be mediated by TLR4 [307]. To date, at least five TLR members (TLR2, TLR4, TLR7, TLR8, and TLR9) have been implicated in induction of HIV-1 expression during opportunistic co-infections [308-313]. Several studies support a role for co-infecting pathogens in HIV transmission and disease. TNF- $\alpha$ levels are elevated in HIV-infected patients co-infected with
Mycobacterium tuberculosis [314]. In another report, a clinical trial evaluating antisense molecules targeting HIV-1 Gag produced unexpected results, and revealed elevated viral loads in treated patients. Several clues led the authors to conclude that the unwanted effect had been the result of TLR9 activation by CpG motifs present in the antisense molecules [309,315,316]. Polymorphisms in the TLR9 gene have been associated with HIV-1 disease progression. Two SNPs $(1635 \mathrm{~A} / \mathrm{G}$ and $+1174 \mathrm{G} / \mathrm{A})$ are found at higher frequency in HAART-naïve rapid progressors (estimated as CD4 count decline) than in normal progressors [317].

Further highlighting the influence of co-infecting pathogens, malaria episodes result in increased viral loads in HIV-infected individuals, a factor that may have influenced the spread of HIV in sub-Saharan Africa [318-320]. Likewise, a study of Kenyan pregnant women has shown that susceptibility to malaria is enhanced up to 2-fold in HIV-infected patients [321]. Interestingly, although malaria did not significantly affect the frequency of mother-to-child transmission according to this report, coinfection with helminth parasites was associated with increased risk of transmission by a mechanism likely involving activation of intrauterine lymphocytes [321]. Importantly, not all co-infecting pathogens increase HIV replication. Infections with GB virus, measles virus, Orientia tsutsugamushi and HTLV type 1 and 2 viruses are known to attenuate HIV infection [322]. Human herpesvirus 6 (HHV-6) and 7 (HHV-7) also suppress HIV replication. Interestingly, these viruses inhibit infection with R5 tropic strains, but minimally affect replication of X4 virus. HHV6 interferes with HIV-1 by upregulating the CCR5 ligand RANTES [323]. Unlike HHV-6, HHV-7 exerts its effect by downregulating $\mathrm{CD} 4$, the cellular receptor shared by HHV-7 and HIV-1 [324]. The R5-specific effect of the inhibition of HIV-1 replication by HHV-7 may be explained by lower affinities for CD4 in R5 envelopes, as compared to T-tropic envelopes.

The FC gamma receptor IIa (CD32) has also been shown to influence HIV pathogenesis. This receptor is expressed in B cells and monocytes, and plays an important role in the removal of antibody-coated infectious agents [325]. One group has evaluated the effect of polymorphisms of the FC gamma receptor IIa gene in HIV-1 perinatal transmission in Kenyan women. The frequency of a His/ His131 SNP is higher in HIV-positive than in HIV-negative children, whereas distribution of an Arg/Arg131 allele is reversed [326]. Another study with a Kenyan cohort found similar conclusions for the same alleles in transmission of placental malaria [327]. Unlike the His131 form, the Arg131 variant does not bind IgG2, however, further experimental evidence is needed to evaluate whether this 
property of the FC gamma receptor is responsible for the observed phenotype.

Cytotoxic T lymphocytes (CTL) play an essential role in the response to HIV infection. It is well accepted that the efficacy of the CTL responses vary among infected individuals and modulate disease progression in vivo $[13,14]$. In addition to HLA variants, other molecules modulate the efficacy of the CTL response. CTL-dependent killing of target cells is mediated by the content of storage granules released near the junction of the CTL and target cell. These granules contain the pore-forming protein perforin, and several serine proteases called granzymes [328]. HIV-specific CTLs from LTNP achieving immunological control proliferate extensively in response to autologous HIVinfected CD4-positive T cells. These LTNP CTLs, unlike those in normal progressors, express higher levels of perforin upon stimulation and proliferation with autologous cells [329]. This suggests that the quality of the CTL response plays an essential role in the response against HIV infection. Supporting this, polymorphisms in the perforin gene have been associated with slower disease progression in a French cohort. The presence of the SNP $1012 \mathrm{~T}$ in the proximal perforin promoter correlates with fewer perforin-positive CTL cells, whereas homozygous individuals $(1012 \mathrm{~T} / \mathrm{T})$ display a trend towards slower disease progression [330].

\section{Conclusion}

To date, considerable progress has been made in identifying allelic variations associated with AIDS progression and HIV-1 transmission. However, this work is beset by problems. These include the polygenic and multifactorial nature of the disease, and the difficulties in isolating the effect of individual allelic variations in genetically diverse cohorts of patients. The complexities of characterizing and recruiting individuals for LTNP and EU cohorts, and the genetic differences between ethnicities have also confounded the characterization of significant associations. Despite this, it is anticipated that in the near future, the map of genes involved in HIV-1 pathogenesis will be greatly enhanced. Identification of these genes and the variants associated with slow progression and resistance to infection will allow physicians to predict better the outcome of disease and to design antiretroviral regimes tailored to patient-specific genotypes. As it has occurred with the CCR5 $\Delta 32$ allele, the discovery of new variants might invigorate the development of approaches to combat HIV1 infection. Furthermore, interpretation of clinical data evaluating anti-HIV drugs and vaccines will also benefit from an understanding of the effects of genetic predisposition/resistance of the patients.

\section{Abbreviations}

CTL, cytotoxic T lymphocyte; CypA, cyclophilin A; EU, highly exposed uninfected individuals; HHV, human herpesvirus; IDU, intravenous drug users; LTNP, long-term nonprogressor; MHC, major histocompatibility complex; MVB, multivesicular body; SNP, single-nucleotide polymorphism; TLR, toll-like receptor.

\section{Competing interests}

The author(s) declare that they have no competing interests.

\section{Authors' contributions}

$\mathrm{JL}$ and VP participating equally in revising the intellectual content and drafting the manuscript. Both authors read and approved the final manuscript.

\section{Acknowledgements}

Carol Kruse and Richard DiScipio are acknowledged for the critical reading of the manuscript. This work was supported, in part, by NIH grants ROI Al49057 and R2I Al62366, to VP and JL, respectively.

\section{References}

I. Buchbinder SP, Katz MH, Hessol NA, O'Malley PM, Holmberg SD: Long-term HIV-I infection without immunologic progression. AIDS I 994, 8(8): | | $23-\mid$ I 28.

2. Anastassopoulou CG, Kostrikis LG: The impact of human allelic variation on HIV-I disease. Curr HIV Res 2003, I(2):185-203.

3. Telenti A, loannidis JP: Susceptibility to HIV infection--disentangling host genetics and host behavior. J Infect Dis 2006, 193(I):4-6.

4. Cunningham AL, Li S, Juarez J, Lynch G, Alali M, Naif H: The level of HIV infection of macrophages is determined by interaction of viral and host cell genotypes. J Leukoc Biol 2000, 68(3):3II-3I7.

5. Blaak H, Ran LJ, Rientsma R, Schuitemaker H: Susceptibility of in vitro stimulated PBMC to infection with NSI HIV-I is associated with levels of CCR5 expression and beta-chemokine production. Virology 2000, 267(2):237-246.

6. Ciuffi A, Bleiber G, Munoz M, Martinez R, Loeuillet C, Rehr M, Fischer M, Gunthard HF, Oxenius A, Meylan P, Bonhoeffer S, Trono D, Telenti $A$ : Entry and transcription as key determinants of differences in CD4 T-cell permissiveness to human immunodeficiency virus type I infection. J Virol 2004, 78(19): 10747-10754.

7. Naif HM, Li S, Alali M, Chang J, Mayne C, Sullivan J, Cunningham AL: Definition of the stage of host cell genetic restriction of replication of human immunodeficiency virus type I in monocytes and monocyte-derived macrophages by using twins. J Virol 1999, 73(6):4866-488।.

8. Chang J, Naif HM, Li S, Sullivan JS, Randle CM, Cunningham AL: Twin studies demonstrate a host cell genetic effect on productive human immunodeficiency virus infection of human monocytes and macrophages in vitro. J Virol 1996, 70( I I):7792-7803.

9. Du Z, Lang SM, Sasseville VG, Lackner AA, Ilyinskii PO, Daniel MD, Jung JU, Desrosiers RC: Identification of a nef allele that causes lymphocyte activation and acute disease in macaque monkeys. Cell 1995, 82(4):665-674.

10. Petrucci A, Dorrucci M, Alliegro MB, Pezzotti P, Rezza G, Sinicco A, Lazzarin A, Angarano G: How many HIV-infected individuals may be defined as long-term nonprogressors? A report from the Italian Seroconversion Study. Italian Seroconversion Study Group (ISS). J Acquir Immune Defic Syndr Hum Retrovirol 1997, 1 4(3):243-248.

II. Shacklett BL: Understanding the "lucky few": the conundrum of HIV-exposed, seronegative individuals. Curr HIVIAIDS Rep 2006, 3(I):26-3I. 
12. Bleiber G, May M, Martinez R, Meylan P, Ott J, Beckmann JS, Telenti A: Use of a combined ex vivo/in vivo population approach for screening of human genes involved in the human immunodeficiency virus type I life cycle for variants influencing disease progression. J Virol 2005, 79(20): I 2674- 12680.

13. Carrington $M$, O'Brien SJ: The influence of HLA genotype on AIDS. Annu Rev Med 2003, 54:535-55I.

14. Kaslow RA, Dorak T, Tang J]: Influence of host genetic variation on susceptibility to HIV type I infection. J Infect Dis 2005, I9 I Suppl I:S68-77.

15. O'Brien SJ, Nelson GW: Human genes that limit AIDS. Nat Genet 2004, 36(6):565-574

16. Pierson TC, Doms RW: HIV-I entry and its inhibition. Curr Top Microbiol Immunol 2003, 28 I: I-27.

17. Arenzana-Seisdedos F, Parmentier M: Genetics of resistance to HIV infection: Role of co-receptors and co-receptor ligands. Semin Immunol 2006, I 8(6):387-403.

18. Feng Y, Broder CC, Kennedy PE, Berger EA: HIV-I entry cofactor: functional cDNA cloning of a seven-transmembrane, $G$ protein-coupled receptor [see comments]. Science 1996 272:872-877.

19. Alkhatib G, Combadiere C, Broder CC, Feng Y, Kennedy PE, Murphy PM, Berger EA: CC CKR5: a rantes, MIP-Ialpha, MIP-Ibeta receptor as fusion cofactor for macrophage tropic HIV-I. Science 1996, 272(5270): 1955-1958.

20. Choe $H$, Farzan $M$, sun $Y$, Sullivan $N$, Rollins $B$, Ponath PD, Wu L, Mackay CR, LaRosa G, Newman W, Gierard N, Gerard C, Sodroski ]: The beta-chemokine receptors CCR3 and CCR5 facilitate infection by primary HIV-I isolates. Cell 1996 85(7): I I 35-| | 48 .

21. Deng H, Liu R, Ellmeier W, Choe S, Unutmaz D, Burkhart M, Di Marzio P, Marmon S, Sutton R, Hill CM, Davis CB, Peiper SC, Schall TJ, Littman DR, Landau NR: Identification of a major co-receptor for primary isolates of HIV-I. Nature 1996, 38 I (6584):66I-666.

22. Doranz BJ, Rucker J, Yi Y, Smyth RJ, Samson M, Peiper SC, Parmentier $M$, Collman RG, Doms RW: A dual-tropic primary HIV-I isolate that uses fusin and the beta-chemokine receptors CKR-5, CKR-3, and CKR-2b as fusion cofactors. Cell 1996, 85(7): $1149-1 \mid 58$

23. Dragic $T$, Litwin $\mathrm{V}$, Allaway GP, Martin SR, Huang $Y$, Nagashima KA, Cayanan C, Maddon PJ, Koup RA, Moore JP, Paxton WA: HIV-I entry into CD4-positive cells is mediated by the chemokine receptor CC-CKR-5. Nature 1996, 38 I(6584):667-673.

24. Liu R, Paxton WA, Choe S, Ceradini D, Martin SR, Horuk R, MacDonald ME, Stuhlmann $H$, Koup RA, Landau NR: Homozygous defect in HIV-I coreceptor accounts for resistance of some multiply-exposed individuals to HIV-I infection. Cell 1996, 86(3):367-377.

25. Dean M, Carrington M, Winkler C, Huttley GA, Smith MW, Allikmets $R$, Goedert IJ, Buchbinder SP, Vittinghoff E, Gomperts E, Donfield S, Vlahov D, Kaslow R, Saah A, Rinaldo C, Detels R, O'Brien S): Genetic restriction of HIV-I infection and progression to AIDS by a deletion allele of the CKR5 structural gene. Hemophilia Growth and Development Study, Multicenter AIDS Cohort Study, Multicenter Hemophilia Cohort Study, San Francisco City Cohort, ALIVE Study. Science 1996, 273(5283): 1856-1862.

26. Samson M, Libert F, Doranz BJ, Rucker J, Liesnard C, Farber CM, Saragosti S, Lapoumeroulie C, Cognaux J, Forceille C, Muyldermans G Verhofstede C, Burtonboy G, Georges M, Imai T, Rana S, Yi Y, Smyth RJ, Collman RG, Doms RW, Vassart G, Parmentier M: Resistance to HIV-I infection in caucasian individuals bearing mutant alleles of the CCR-5 chemokine receptor gene. Nature 1996, 382(6593):722-725

27. Benkirane M, Jin DY, Chun RF, Koup RA, Jeang KT: Mechanism of transdominant inhibition of CCR5-mediated HIV-I infection by ccr5delta32. I Biol Chem 1997, 272(49):30603-30606.

28. Lederman MM, Penn-Nicholson A, Cho M, Mosier D: Biology of CCR5 and its role in HIV infection and treatment. Jama 2006, 296(7):8I5-826.

29. Stephens JC, Reich DE, Goldstein DB, Shin HD, Smith MW, Carrington M, Winkler C, Huttley GA, Allikmets R, Schriml L, Gerrard B, Malasky M, Ramos MD, Morlot S, Tzetis M, Oddoux C, di Giovine FS, Nasioulas G, Chandler D, Aseev M, Hanson M, Kalaydjieva L, Glavac D, Gasparini P, Kanavakis E, Claustres M, Kambouris M, Ostrer H, Duff G, Baranov V, Sibul H, Metspalu A, Goldman D, Martin N, Duffy
D, Schmidtke J, Estivill X, O'Brien SJ, Dean M: Dating the origin of the CCR5-Delta32 AIDS-resistance allele by the coalescence of haplotypes. Am J Hum Genet 1998, 62(6): 1507-1515.

30. Salkowitz JR, Purvis SF Meyerson H, Zimmerman P O'Brien TR, Aledort L, Eyster ME, Hilgartner M, Kessler C, Konkle BA, White GC 2nd, Goedert J], Lederman MM: Characterization of high-risk HIV-I seronegative hemophiliacs. Clin Immunol 200I, 98(2):200-2II.

31. Naif HM, Cunningham AL, Alali M, Li S, Nasr N, Buhler MM, Schols $D$, de Clercq $E$, Stewart G: A human immunodeficiency virus type I isolate from an infected person homozygous for CCR5Delta32 exhibits dual tropism by infecting macrophages and MT2 cells via CXCR4. J Virol 2002, 76(7):3। I4-3I 24.

32. Gorry PR, Zhang C, Wu S, Kunstman K, Trachtenberg E, Phair J, Wolinsky S, Gabuzda D: Persistence of dual-tropic HIV-I in an individual homozygous for the CCR5 Delta 32 allele. Lancet 2002, 359(9320): 1832-1834.

33. Michael NL, Nelson JA, KewalRamani VN, Chang G, O'Brien SJ, Mascola JR, Volsky B, Louder M, White GC 2nd, Littman DR, Swanstrom $R, O ' B r i e n$ TR: Exclusive and persistent use of the entry coreceptor CXCR4 by human immunodeficiency virus type I from a subject homozygous for CCR5 delta32. J Virol 1998, 72(7):6040-6047.

34. Balotta C, Bagnarelli P, Violin M, Ridolfo AL, Zhou D, Berlusconi A, Corvasce S, Corbellino M, Clementi M, Clerici M, Moroni M, Galli M: Homozygous delta 32 deletion of the CCR-5 chemokine receptor gene in an HIV-I-infected patient. AIDS 1997, II (I0):F67-7I.

35. Kuipers H, Workman C, Dyer W, Geczy A, Sullivan J, Oelrichs R: An HIV-I-infected individual homozygous for the CCR-5 delta32 allele and the SDF-I 3'A. allele. AIDS 1999, 13(3):433-434.

36. O'Brien TR, Winkler C, Dean M, Nelson JA, Carrington M, Michael NL, White GC 2nd: HIV-I infection in a man homozygous for CCR5 delta 32. Lancet 1997, 349(9060): 1219.

37. Theodorou I, Meyer L, Magierowska M, Katlama C, Rouzioux C: HIV-I infection in an individual homozygous for CCR5 delta 32. Seroco Study Group. Lancet 1997, 349(9060): $1219-1220$.

38. Cohen OJ, Paolucci S, Bende SM, Daucher M, Moriuchi H, Moriuchi M, Cicala C, Davey RT Jr., Baird B, Fauci AS: CXCR4 and CCR5 genetic polymorphisms in long-term nonprogressive human immunodeficiency virus infection: lack of association with mutations other than CCR5-Delta32. I Virol 1998, 72(7):6215-6217.

39. Huang $Y$, Paxton WA, Wolinsky SM, Neumann AU, Zhang L, He T, Kang S, Ceradini D, Jin Z, Yazdanbakhsh K, Kunstman K, Erickson D, Dragon E, Landau NR, Phair J, Ho DD, Koup RA: The role of a mutant CCR5 allele in HIV-I transmission and disease progression. Nat Med 1996, 2(I I): 1240-I 243.

40. Smith MW, Dean M, Carrington M, Winkler C, Huttley GA, Lomb DA, Goedert IJ, O'Brien TR, Jacobson LP, Kaslow R, Buchbinder S, Vittinghoff E, Vlahov D, Hoots K, Hilgartner MW, O'Brien SJ: Contrasting genetic influence of CCR2 and CCR5 variants on HIV-I infection and disease progression. Hemophilia Growth and Development Study (HGDS), Multicenter AIDS Cohort Study (MACS), Multicenter Hemophilia Cohort Study (MHCS), San Francisco City Cohort (SFCC), ALIVE Study. Science 1997, 277(5328):959-965

4I. Stewart G], Ashton LJ, Biti RA, Ffrench RA, Bennetts BH, Newcombe NR, Benson EM, Carr A, Cooper DA, Kaldor JM: Increased frequency of CCR-5 delta 32 heterozygotes among long-term non-progressors with HIV-I infection. The Australian LongTerm Non-Progressor Study Group. AIDS 1997, I I(I5): | 833-1838.

42. Eskild A, Jonassen TO, Heger B, Samuelsen SO, Grinde B: The estimated impact of the CCR-5 delta32 gene deletion on HIV disease progression varies with study design. Oslo HIV Cohort Study Group. AIDS 1998, I 2(I7):227I-2274.

43. Schinkel J, Langendam MW, Coutinho RA, Krol A, Brouwer M, Schuitemaker $\mathrm{H}$ : No evidence for an effect of the CCR5 delta32/+ and CCR2b $641 /+$ mutations on human immunodeficiency virus (HIV)-I disease progression among HIV-I-infected injecting drug users. J Infect Dis 1999, I79(4):825-83 I.

44. Wilkinson DA, Operskalski EA, Busch MP, Mosley JW, Koup RA: A 32-bp deletion within the CCR5 locus protects against transmission of parenterally acquired human immunodeficiency 
virus but does not affect progression to AIDS-defining illness. J Infect Dis 1998, 178(4): I 163-1 I66.

45. Morawetz RA, Rizzardi GP, Glauser D, Rutschmann O, Hirschel B, Perrin L, Opravil M, Flepp M, von Overbeck J, Glauser MP, Ghezzi S, Vicenzi E, Poli G, Lazzarin A, Pantaleo G: Genetic polymorphism of CCR5 gene and HIV disease: the heterozygous (CCR5/ delta ccr5) genotype is neither essential nor sufficient for protection against disease progression. Swiss HIV Cohort. Eur J Immunol I 997, 27( I 2):3223-3227.

46. Reynes J, Portales P, Segondy M, Baillat V, Andre P, Avinens O, Picot MC, Clot J, Eliaou JF, Corbeau P: CD4 T cell surface CCR5 density as a host factor in HIV-I disease progression. AIDS 200I, I5(13): 1627-1634.

47. Reynes J, Portales P, Segondy M, Baillat $V$, Andre P, Reant B, Avinens O, Couderc G, Benkirane M, Clot J, Eliaou JF, Corbeau P: CD4 T cell surface CCR5 density as a determining factor of virus load in persons infected with human immunodeficiency virus type $I$. Inf Dis 2000, 181:927-932.

48. Wu L, Paxton WA, Kassam N, Ruffing N, Rottman JB, Sullivan N, Choe H, Sodroski J, Newman W, Koup RA, Mackay CR: CCR5 levels and expression pattern correlate with infectability by macrophage-tropic HIV-I, in vitro. J Exp Med 1997, | 85(9): |68|-|69|.

49. Blanpain C, Lee B, Tackoen M, Puffer B, Boom A, Libert F, Sharron M, Wittamer V, Vassart G, Doms RW, Parmentier M: Multiple nonfunctional alleles of CCR5 are frequent in various human populations. Blood 2000, 96(5): I638-1645.

50. Capoulade-Metay C, Trong LX, Dudoit Y, Versmisse P, Nguyen NV, Nguyen M, Scott-Algara D, Barre-Sinoussi F, Debre P, Bismuth G, Pancino G, Theodorou I: New CCR5 variants associated with reduced HIV coreceptor function in southeast Asia. AIDS 2004, I 8(I7):2243-2252.

5I. Carrington M, Kissner T, Gerrard B, Ivanov S, O'Brien SJ, Dean M: Novel alleles of the chemokine-receptor gene CCR5. Am J Hum Genet 1997, 61(6): | 26I- I267.

52. Quillent C, Oberlin E, Braun J, Rousset D, Gonzalez-Canali G, Metais P, Montagnier L, Virelizier JL, Arenzana-Seisdedos F, Beretta A: HIVI-resistance phenotype conferred by combination of two separate inherited mutations of CCR5 gene. Lancet 1998, 35I(9095): | $4-18$.

53. Martin MP, Dean M, Smith MW, Winkler C, Gerrard B, Michael NL, Lee B, Doms RW, Margolick J, Buchbinder S, Goedert J], O'Brien TR, Hilgartner MW, Vlahov D, O'Brien SJ, Carrington M: Genetic acceleration of AIDS progression by a promoter variant of CCR5. Science 1998, 282(5395): |907-19|1.

54. Clegg AO, Ashton LJ, Biti RA, Badhwar P, Williamson P, Kaldor JM, Stewart G]: CCR5 promoter polymorphisms, CCR5 59029A and CCR5 59353C, are under represented in HIV-I-infected long-term non-progressors. The Australian Long-Term Non-Progressor Study Group. AIDS 2000, 14(2): $103-108$

55. Hladik F, Liu H, Speelmon E, Livingston-Rosanoff D, Wilson S, Sakchalathorn P, Hwangbo Y, Greene B, Zhu T, McElrath MJ: Combined effect of CCR5-Delta32 heterozygosity and the CCR5 promoter polymorphism -2459 A/G on CCR5 expression and resistance to human immunodeficiency virus type I transmission. J Virol 2005, 79(18): 11677-11684.

56. Pastori C, Weiser B, Barassi C, Uberti-Foppa C, Ghezzi S, Longhi R, Calori G, Burger H, Kemal K, Poli G, Lazzarin A, Lopalco L: Longlasting CCR5 internalization by antibodies in a subset of long-term nonprogressors: a possible protective effect against disease progression. Blood 2006, I 07( I 2):4825-4233.

57. Bouhlal H, Latry V, Requena M, Aubry S, Kaveri SV, Kazatchkine MD, Belec L, Hocini H: Natural antibodies to CCR5 from breast milk block infection of macrophages and dendritic cells with primary R5-tropic HIV-I. J Immunol 2005, I 74(I I):7202-7209.

58. Barassi C, Soprana E, Pastori C, Longhi R, Buratti E, Lillo F, Marenzi C, Lazzarin A, Siccardi AG, Lopalco L: Induction of murine mucosal CCR5-reactive antibodies as an anti-human immunodeficiency virus strategy. J Virol 2005, 79(I I):6848-6458.

59. Ray N, Doms RW: HIV-I coreceptors and their inhibitors. Curr Top Microbiol Immunol 2006, 303:97-I20.

60. Kilby JM, Eron J]: Novel therapies based on mechanisms of HIV-I cell entry. N Engl J Med 2003, 348(22):2228-2238.

6I. Fatkenheuer G, Pozniak AL, Johnson MA, Plettenberg A, Staszewski S, Hoepelman AI, Saag MS, Goebel FD, Rockstroh JK, Dezube BJ, Jenkins TM, Medhurst C, Sullivan JF, Ridgway C, Abel S, James IT,
Youle M, van der Ryst E: Efficacy of short-term monotherapy with maraviroc, a new CCR5 antagonist, in patients infected with HIV-I. Nat Med 2005, I I(I I): I I70-I I 72.

62. Smith MW, Carrington M, Winkler C, Lomb D, Dean M, Huttley G, O'Brien SJ: CCR2 chemokine receptor and AIDS progression. Nat Med 1997, 3(10):1052-1053.

63. Michael NL, Louie LG, Rohrbaugh AL, Schultz KA, Dayhoff DE, Wang CE, Sheppard HW: The role of CCR5 and CCR2 polymorphisms in HIV-I transmission and disease progression. Nat Med 1997, 3(10): I I60-II62.

64. Lee B, Doranz BJ, Rana S, Yi Y, Mellado M, Frade JM, Martinez AC, O'Brien SJ, Dean M, Collman RG, Doms RW: Influence of the CCR2-V64I polymorphism on human immunodeficiency virus type I coreceptor activity and on chemokine receptor function of CCR2b, CCR3, CCR5, and CXCR4. J Virol 1998, 72(9):7450-7458

65. Mariani R, Wong S, Mulder LC, Wilkinson DA, Reinhart AL, LaRosa G, Nibbs R, O'Brien TR, Michael NL, Connor RI, Macdonald M, Busch $M$, Koup RA, Landau NR: CCR2-64I polymorphism is not associated with altered CCR5 expression or coreceptor function. J Virol 1999, 73(3):2450-2459.

66. Nakayama EE, Tanaka Y, Nagai Y, Iwamoto A, Shioda T: A CCR2V64I polymorphism affects stability of CCR2A isoform. AIDS 2004, 18(5):729-738.

67. Mellado M, Rodriguez-Frade JM, Vila-Coro AJ, de Ana AM, Martinez AC: Chemokine control of HIV-I infection. Nature 1999, 400(6746):723-724.

68. Imai T, Hieshima K, Haskell C, Baba M, Nagira M, Nishimura M, Kakizaki M, Takagi S, Nomiyama H, Schall TJ, Yoshie O: Identification and molecular characterization of fractalkine receptor CX3CRI, which mediates both leukocyte migration and adhesion. Cell I997, 9 I (4):52I-530.

69. Faure S, Meyer L, Costagliola D, Vaneensberghe C, Genin E, Autran B, Delfraissy JF, McDermott DH, Murphy PM, Debre P, Theodorou I, Combadiere C: Rapid progression to AIDS in HIV+ individuals with a structural variant of the chemokine receptor CX3CRI. Science 2000, 287(546I):2274-2277.

70. Singh KK, Hughes MD, Chen J, Spector SA: Genetic polymorphisms in CX3CRI predict HIV-I disease progression in children independently of CD4+ lymphocyte count and HIV-I RNA load. J Infect Dis 2005, I 9 I(II): 197I-1980.

7I. Brumme ZL, Dong WW, Chan KJ, Hogg RS, Montaner JS, O'Shaughnessy MV, Harrigan PR: Influence of polymorphisms within the CX3CRI and MDR-I genes on initial antiretroviral therapy response. AIDS 2003, I 7(2):20I-208.

72. Vidal F, Vilades C, Domingo P, Broch M, Pedrol E, Dalmau D, Knobel H, Peraire J, Gutierrez C, Sambeat MA, Fontanet A, Deig E, Cairo M, Montero M, Richart C, Mallal S: Spanish HIV-I-infected longterm nonprogressors of more than 15 years have an increased frequency of the CX3CRI 249I variant allele. J Acquir Immune Defic Syndr 2005, 40(5):527-53I.

73. Kwa D, Boeser-Nunnink B, Schuitemaker $H$ : Lack of evidence for an association between a polymorphism in CX3CRI and the clinical course of HIV infection or virus phenotype evolution. AIDS 2003, I7(5):759-76I.

74. Puissant B, Roubinet F, Massip P, Sandres-Saune K, Apoil PA, Abbal M, Pasquier C, Izopet J, Blancher A: Analysis of CCR5, CCR2, CX3CRI, and SDFI polymorphisms in HIV-positive treated patients: impact on response to HAART and on peripheral T lymphocyte counts. AIDS Res Hum Retroviruses 2006, 22(2): $153-162$.

75. McDermott DH, Colla JS, Kleeberger CA, Plankey M, Rosenberg PS, Smith ED, Zimmerman PA, Combadiere C, Leitman SF, Kaslow RA, Goedert IJ, Berger EA, O'Brien TR, Murphy PM: Genetic polymorphism in CX3CRI and risk of HIV disease. Science 2000, 290(5499):2031.

76. Faure S, Meyer L, Genin E, Pellet P, Debre P, Theodorou I, Combadiere $C$ : Deleterious genetic influence of CX3CRI genotypes on HIV-I disease progression. J Acquir Immune Defic Syndr 2003, 32(3):335-337.

77. Koot M, Keet IP, Vos AH, de Goede RE, Roos MT, Coutinho RA, Miedema F, Schellekens PT, Tersmette M: Prognostic value of HIV-I syncytium-inducing phenotype for rate of CD4+ cell depletion and progression to AIDS. Ann Intern Med 1993, I | 8(9):68I-688. 
78. Cheng-Mayer C, Seto D, Tateno M, Levy JA: Biologic features of HIV-I that correlate with virulence in the host. Science 1988 , 240(4848):80-82.

79. Schuitemaker $H$, Koot M, Kootstra NA, Dercksen MW, de Goede RE, van Steenwijk RP, Lange JM, Schattenkerk JK, Miedema F, Tersmette $M$ : Biological phenotype of human immunodeficiency virus type I clones at different stages of infection: progression of disease is associated with a shift from monocytotropic to T-cell-tropic virus population. J Virol 1992, 66(3): $1354-1360$.

80. Ho SH, Shek L, Gettie A, Blanchard J, Cheng-Mayer C: V3 loopdetermined coreceptor preference dictates the dynamics of CD4+-T-cell loss in simian-human immunodeficiency virusinfected macaques. J Virol 2005, 79( (19): I 2296-I2303.

81. Karlsson I, Antonsson L, Shi Y, Karlsson A, Albert J, Leitner T, Olde $B$, Owman C, Fenyo EM: HIV biological variability unveiled: frequent isolations and chimeric receptors reveal unprecedented variation of coreceptor use. AIDS 2003, I 7( I 8):256|-2569.

82. Lusso P: HIV and the chemokine system: 10 years later. Embo J 2006, 25(3):447-456.

83. Agace WW, Amara A, Roberts AI, Pablos JL, Thelen S, Uguccioni M, Li XY, Marsal J, Arenzana-Seisdedos F, Delaunay T, Ebert EC, Moser $B$, Parker CM: Constitutive expression of stromal derived factor-I by mucosal epithelia and its role in HIV transmission and propagation. Curr Biol 2000, I 0(6):325-328.

84. Bunnik EM, Quakkelaar ED, van Nuenen AC, Boeser-Nunnink B, Schuitemaker $\mathrm{H}$ : Increased neutralization sensitivity of recently emerged CXCR4-using human immunodeficiency virus type I strains compared to coexisting CCR5-using variants from the same patient. J Virol 2007, 8 I (2):525-53I.

85. Marodon G, Warren D, Filomio MC, Posnett DN: Productive infection of double-negative T cells with HIV in vivo. Proc Natl Acad Sci USA 1999, 96(21): I 1958-1 I 963.

86. Menten $\mathrm{P}$, Wuyts $\mathrm{A}$, Van Damme J: Macrophage inflammatory protein- I. Cytokine Growth Factor Rev 2002, I 3(6):455-48I

87. Cocchi F, DeVico AL, Garzino-Demo A, Arya SK, Gallo RC, Lusso P. Identification of RANTES, MIP-I alpha, and MIP-I beta as the major HIV-suppressive factors produced by CD8+ T cells. Science $1995, \mathbf{2 7 0}(\mathbf{5 2 4 3}):|8||-| 8 \mid 5$.

88. Ullum H, Cozzi Lepri A, Victor J, Aladdin H, Phillips AN, Gerstoft J, Skinhoj P, Pedersen BK: Production of beta-chemokines in human immunodeficiency virus (HIV) infection: evidence that high levels of macrophage inflammatory protein-Ibeta are associated with a decreased risk of HIV disease progression. J Infect Dis 1998, I77(2):331-336.

89. Saha K, Bentsman G, Chess L, Volsky DJ: Endogenous production of beta-chemokines by CD4+, but not CD8+, T-cell clones correlates with the clinical state of human immunodeficiency virus type I (HIV-I)-infected individuals and may be responsible for blocking infection with non-syncytium-inducing HIV-I in vitro. J Virol I998, 72(I):876-88I.

90. Koning FA, Jansen CA, Dekker J, Kaslow RA, Dukers N, van Baarle D, Prins M, Schuitemaker $\mathrm{H}$ : Correlates of resistance to HIV-I infection in homosexual men with high-risk sexual behaviour. AIDS 2004, I 8(8): I | |7-I| 26.

91. Saez-Cirion A, Versmisse P, Truong LX, Chakrabarti LA, Carpentier W, Barre-Sinoussi F, Scott-Algara D, Pancino G: Persistent resistance to HIV-I infection in CD4 T cells from exposed uninfected Vietnamese individuals is mediated by entry and postentry blocks. Retrovirology 2006, 3:81.

92. Amara A, Gall SL, Schwartz O, Salamero J, Montes M, Loetscher P, Baggiolini M, Virelizier JL, Arenzana-Seisdedos F: HIV coreceptor downregulation as antiviral principle: SDF-I alpha-dependent internalization of the chemokine receptor CXCR4 contributes to inhibition of HIV replication. J Exp Med 1997, I 86(I): $139-146$.

93. Modi WS, Lautenberger J, An P, Scott K, Goedert JJ, Kirk GD, Buchbinder S, Phair J, Donfield S, O'Brien SJ, Winkler C: Genetic variation in the CCLI8-CCL3-CCL4 chemokine gene cluster influences HIV Type I transmission and AIDS disease progression. Am J Hum Genet 2006, 79(I): I20-I28.

94. Vidal F, Peraire J, Domingo P, Broch M, Cairo M, Pedrol E, Montero M, Vilades C, Gutierrez C, Sambeat MA, Fontanet A, Dalmau D, Deig E, Knobel H, Sirvent I], Richart C, Veloso S, Saumoy M, Lopez-Dupla M, Olona M, Cadafalch J, Fuster M, Ochoa A, Soler A, Guelar A,
Gonzalez J: Polymorphism of RANTES chemokine gene promoter is not associated with long-term nonprogressive HIVI infection of more than 16 years. J Acq ImM Def Syndr 2006, 4I(I): I7-22.

95. Irving SG, Zipfel PF, Balke J, McBride OW, Morton CC, Burd PR, Siebenlist $U$, Kelly K: Two inflammatory mediator cytokine genes are closely linked and variably amplified on chromosome I 7q. Nucleic Acids Res 1990, I 8(I I):326I-3270.

96. Gonzalez E, Kulkarni H, Bolivar H, Mangano A, Sanchez R, Catano G Nibbs RJ, Freedman BI, Quinones MP, Bamshad MJ, Murthy KK, Rovin BH, Bradley W, Clark RA, Anderson SA, O'Connell R J, Agan BK, Ahuja SS, Bologna R, Sen L, Dolan MJ, Ahuja SK: The influence of CCL3LI gene-containing segmental duplications on HIV-I/ AIDS susceptibility. Science 2005, 307(57 | 4): |434- | 440.

97. Colobran R, Adreani P, Ashhab Y, Llano A, Este JA, Dominguez $O$ Pujol-Borrell $R$, Juan $M$ : Multiple products derived from two CCL4 loci: high incidence of a new polymorphism in HIV+ patients. J Immunol 2005, I 74(9):5655-5664.

98. Gallo RC, Garzino-Demo A, DeVico AL: HIV infection and pathogenesis: what about chemokines? J Clin Immunol 1999, I9(5):293-299.

99. Zagury D, Lachgar A, Chams V, Fall LS, Bernard J, Zagury JF, Bizzini B, Gringeri A, Santagostino E, Rappaport J, Feldman M, O'Brien S], Burny A, Gallo RC: C-C chemokines, pivotal in protection against HIV type I infection. Proc Natl Acad Sci U S A 1998 , 95(7):3857-386I.

100. Liu H, Chao D, Nakayama EE, Taguchi H, Goto M, Xin X, Takamatsu JK, Saito H, Ishikawa Y, Akaza T, Juji T, Takebe Y, Ohishi T, Fukutake K, Maruyama Y, Yashiki S, Sonoda S, Nakamura T, Nagai Y, Iwamoto A, Shioda T: Polymorphism in RANTES chemokine promoter affects HIV-I disease progression. Proc Natl Acad Sci U S A 1999, 96(8):458I-4585.

I0I. Wichukchinda N, Nakayama EE, Rojanawiwat A, Pathipvanich P, Auwanit W, Vongsheree S, Ariyoshi K, Sawanpanyalert P, Shioda T: Protective effects of IL4-589T and RANTES-28G on HIV-I disease progression in infected Thai females. AIDS 2006, 20(2): $189-196$.

102. Zhao XY, Lee SS, Wong KH, Chan KC, Ma S, Yam WC, Yuen KY, Ng $\mathrm{MH}$, Zheng $\mathrm{B}$ : Effects of single nucleotide polymorphisms in the RANTES promoter region in healthy and HIV-infected indigenous Chinese. Eur J Immunogenet 2004, 3 I (4): I 79-I83.

103. McDermott DH, Beecroft MJ, Kleeberger CA, Al-Sharif FM, Ollier WE, Zimmerman PA, Boatin BA, Leitman SF, Detels R, Hajeer AH, Murphy PM: Chemokine RANTES promoter polymorphism affects risk of both HIV infection and disease progression in the Multicenter AIDS Cohort Study. Aids 2000, | 4( I 7):267|-2678.

104. Fernandez RM, Borrego S, Marcos I, Rubio A, Lissen E, Antinolo G: Fluorescence resonance energy transfer analysis of the RANTES polymorphisms $-403 G$-.> A and -28G --> C: evaluation of both variants as susceptibility factors to HIV type I infection in the Spanish population. AIDS Res Hum Retroviruses 2003, I 9(5):349-352.

105. Winkler C, An P, O'Brien SJ: Patterns of ethnic diversity among the genes that influence AIDS. Hum Mol Genet 2004, I 3 Spec No I:R9-19.

106. An P, Nelson GW, Donfield S, Goederrt JJ, Phair J, Vlahov D, Buchbinder S, Farrar WL, Modi W, O'Brien S J, Winkler CA: Modulating influence on HIVIAIDS by interacting RANTES gene variants. Proc Natl Acad Sci USA 2002, 99( I 5): 10002-10007.

107. Bleul CC, Farzan M, Choe H, Parolin C, Clark-Lewis I, Sodroski J, Springer TA: The lymphocyte chemoattractant SDF-I is a ligand for LESTR/fusin and blocks HIV-I entry. Nature 1996, 382(6594):829-833.

108. Oberlin E, Amara A, Bachelerie F, Bessia C, Virelizier JL, ArenzanaSeisdedos F, Schwartz O, Heard JM, Clark-Lewis I, Legler DF, Loetscher M, Baggiolini M, Moser B: The CXC chemokine SDF-I is the ligand for LESTR/fusin and prevents infection by $T$-cellline-adapted HIV-I. Nature 1996, 382(6594):833-835.

109. Signoret N, Oldridge J, Pelchen-Matthews A, Klasse PJ, Tran T, Brass LF, Rosenkilde MM, Schwartz TW, Holmes W, Dallas W, Luther MA, Wells TN, Hoxie JA, Marsh M: Phorbol esters and SDF-I induce rapid endocytosis and down modulation of the chemokine receptor CXCR4. J Cell Biol I997, I39(3):65 I-664.

I 10. Ma Q, Jones D, Borghesani PR, Segal RA, Nagasawa T, Kishimoto T, Bronson RT, Springer TA: Impaired B-lymphopoiesis, myelopoi- 
esis, and derailed cerebellar neuron migration in CXCR4and SDF-I-deficient mice. Proc Natl Acad Sci USA 1998, 95(16):9448-9453.

III. Nagasawa T, Hirota S, Tachibana K, Takakura N, Nishikawa S, Kitamura Y, Yoshida N, Kikutani H, Kishimoto T: Defects of B-cell lymphopoiesis and bone-marrow myelopoiesis in mice lacking the CXC chemokine PBSF/SDF-I. Nature 1996, 382(6592):635-638.

1 12. Arya SK, Ginsberg CC, Davis-Warren A, D'Costa J: In vitro phenotype of SDFI gene mutant that delays the onset of human immunodeficiency virus disease in vivo. J Hum Virol 1999, 2(3): $133-138$.

113. Winkler C, Modi W, Smith MW, Nelson GW, Wu X, Carrington M, Dean M, Honjo T, Tashiro K, Yabe D, Buchbinder S, Vittinghoff E, Goedert J], O'Brien TR, Jacobson LP, Detels R, Donfield S, Willoughby A, Gomperts E, Vlahov D, Phair J, O'Brien SJ: Genetic restriction of AIDS pathogenesis by an SDF-I chemokine gene variant. ALIVE Study, Hemophilia Growth and Development Study (HGDS), Multicenter AIDS Cohort Study (MACS), Multicenter Hemophilia Cohort Study (MHCS), San Francisco City Cohort (SFCC). Science 1998, 279(5349):389-393.

1 14. Hendel $\mathrm{H}$, Henon $\mathrm{N}$, Lebuanec $\mathrm{H}$, Lachgar $\mathrm{A}$, Poncelet $\mathrm{H}$, Caillat-Zucman S, Winkler CA, Smith MW, Kenefic L, O'Brien S, Lu W, Andrieu JM, Zagury D, Schachter F, Rappaport J, Zagury JF: Distinctive effects of CCR5, CCR2, and SDFI genetic polymorphisms in AIDS progression. J Acquir Immune Defic Syndr Hum Retrovirol I998, 19(4):38I-386.

I I5. loannidis JP, Rosenberg PS, Goedert JJ, Ashton LJ, Benfield TL, Buchbinder SP, Coutinho RA, Eugen-Olsen J, Gallart T, Katzenstein TL, Kostrikis LG, Kuipers H, Louie LG, Mallal SA, Margolick JB, Martinez OP, Meyer L, Michael NL, Operskalski E, Pantaleo G, Rizzardi GP, Schuitemaker H, Sheppard HW, Stewart GJ, Theodorou ID, Ullum H, Vicenzi E, Vlahov D, Wilkinson D, Workman C, Zagury JF, O'Brien TR: Effects of CCR5-Delta32, CCR2-64I, and SDF-I 3'A alleles on HIV-I disease progression: An international metaanalysis of individual-patient data. Ann Intern Med 200I, 135(9):782-795.

116. Magierowska M, Lepage V, Lien TX, Lan NT, Guillotel M, Issafras H, Reynes JM, Fleury HJ, Chi NH, Follezou JY, Debre P, Theodorou I, Barre-Sinoussi F: Novel variant of the CCR5 gene in a Vietnamese population. Microbes Infect 1999, I(2): I23-124.

I 17. Petersen DC, Glashoff RH, Shrestha S, Bergeron J, Laten A, Gold B, van Rensburg EJ, Dean M, Hayes VM: Risk for HIV-I infection associated with a common CXCLI 2 (SDFI) polymorphism and CXCR4 variation in an African population. J Acquir Immune Defic Syndr 2005, 40(5):52I-526.

1 18. Modi WS, Goedert J], Strathdee S, Buchbinder S, Detels R, Donfield S, O'Brien SJ, Winkler C: MCP-I-MCP-3-Eotaxin gene cluster influences HIV-I transmission. AIDS 2003, I7(16):2357-2365.

I19. Ji X, Gewurz H, Spear GT: Mannose binding lectin (MBL) and HIV. Mol Immunol 2005, 42(2): I45-I52.

120. Turville $S$, Wilkinson J, Cameron P, Dable J, Cunningham AL: The role of dendritic cell C-type lectin receptors in HIV pathogenesis. J Leukoc Biol 2003, 74(5):710-718.

121. Kwon DS, Gregorio G, Bitton N, Hendrickson WA, Littman DR: DCSIGN-mediated internalization of HIV is required for transenhancement of T cell infection. Immunity 2002, I 6(I): I 35- I 44.

122. Burleigh L, Lozach PY, Schiffer C, Staropoli I, Pezo V, Porrot F, Canque B, Virelizier JL, Arenzana-Seisdedos F, Amara A: Infection of dendritic cells (DCs), not DC-SIGN-mediated internalization of human immunodeficiency virus, is required for longterm transfer of virus to T cells. J Virol 2006, 80(6):2949-2957.

123. Martin MP, Lederman MM, Hutcheson HB, Goedert J], Nelson GW, van Kooyk Y, Detels R, Buchbinder S, Hoots K, Vlahov D, O'Brien SJ, Carrington M: Association of DC-SIGN promoter polymorphism with increased risk for parenteral, but not mucosal, acquisition of human immunodeficiency virus type $I$ infection. J Virol 2004, 78(24): I 4053-I 4056.

124. Gramberg T, Zhu T, Chaipan C, Marzi A, Liu H, Wegele A, Andrus T, Hofmann H, Pohlmann S: Impact of polymorphisms in the DCSIGNR neck domain on the interaction with pathogens. Virology 2006, 347(2):354-363.

125. Liu H, Hwangbo Y, Holte S, Lee J, Wang C, Kaupp N, Zhu H, Celum C, Corey L, McElrath MJ, Zhu T: Analysis of genetic polymorphisms in CCR5, CCR2, stromal cell-derived factor-I,
RANTES, and dendritic cell-specific intercellular adhesion molecule-3-grabbing nonintegrin in seronegative individuals repeatedly exposed to HIV-I. J Infect Dis 2004, I 90(6): | 055-1058.

126. Santos PR, Michel-Salzat A, Butor C: Chimpanzee DC-SIGN alleles predict the existence of $A$ and $B$ isoforms, but do not support a role for resistance to HIV infection. AIDS Res Hum Retroviruses 2005, 21 (9):820-829.

127. Fahrbach KM, Barry SM, Ayehunie S, Lamore S, Klausner M, Hope T]: Activated CD34-Derived Langerhans Cells Mediate Transinfection with Human Immunodeficiency Virus. J Virol 2007, 8I(I3):6858-6868.

128. de Witte L, Nabatov A, Pion M, Fluitsma D, de Jong MA, de Gruijl T, Piguet $\mathrm{V}$, van Kooyk $\mathrm{Y}$, Geijtenbeek TB: Langerin is a natural barrier to HIV-I transmission by Langerhans cells. Nat Med 2007, 13(3):367-37|.

129. Schwartz O: Langerhans cells lap up HIV-I. Nat Med 2007, 13(3):245-246.

130. Verdijk P, Dijkman R, Plasmeijer El, Mulder AA, Zoutman WH, Mieke Mommaas A, Tensen CP: A lack of Birbeck granules in Langerhans cells is associated with a naturally occurring point mutation in the human Langerin gene. J Invest Dermatol 2005 , | 24(4):7|4-7|7.

13I. Daher KA, Selsted ME, Lehrer RI: Direct inactivation of viruses by human granulocyte defensins. J Virol 1986, 60(3): I068-1074.

132. Ganz T, Selsted ME, Szklarek D, Harwig SS, Daher K, Bainton DF, Lehrer RI: Defensins. Natural peptide antibiotics of human neutrophils. J Clin Invest 1985, 76(4): | 427-| 435.

133. Cole AM, Ganz T: Human antimicrobial peptides: analysis and application. Biotechniques 2000, 29(4):822-6, 828, 830-I.

134. Jenssen $\mathrm{H}$, Hamill $\mathrm{P}$, Hancock RE: Peptide antimicrobial agents. Clin Microbiol Rev 2006, I 9(3):49 I-5I I.

135. Klotman ME, Chang TL: Defensins in innate antiviral immunity. Nat Rev Immunol 2006, 6(6):447-456.

136. Nakashima H, Yamamoto N, Masuda M, Fujii N: Defensins inhibit HIV replication in vitro. AIDS I993, 7(8): I I 29.

137. Tang YQ, Yuan J, Osapay G, Osapay K, Tran D, Miller C], Ouellette AJ, Selsted ME: A cyclic antimicrobial peptide produced in primate leukocytes by the ligation of two truncated alphadefensins. Science 1999, 286(5439):498-502.

138. Cole AM, Lehrer RI: Minidefensins: antimicrobial peptides with activity against HIV-I. Curr Pharm Des 2003, 9(18): I463-I473.

139. Cole AM, Hong T, Boo LM, Nguyen T, Zhao C, Bristol G, Zack JA, Waring AJ, Yang OO, Lehrer RI: Retrocyclin: a primate peptide that protects cells from infection by $\mathrm{T}$ - and M-tropic strains of HIV-I. Proc Natl Acad Sci USA 2002, 99(4): I8I3-18I8.

140. Gallo SA, Wang W, Rawat SS, Jung G, Waring AJ, Cole AM, Lu H, Yan $X$, Daly NL, Craik DJ, Jiang S, Lehrer RI, Blumenthal R: Thetadefensins prevent HIV-I Env-mediated fusion by binding gp4I and blocking 6-helix bundle formation. J Biol Chem 2006, 28 I (27): | 8787- | 8792.

14I. Furci L, Sironi F, Tolazzi M, Vassena L, Lusso P: Alpha-defensins block the early steps of HIV-I infection: interference with the binding of gp I 20 to CD4. Blood 2007, 109(7):2928-2935.

142. Chang TL, Vargas J Jr., DelPortillo A, Klotman ME: Dual role of alpha-defensin-I in anti-HIV-I innate immunity. I Clin Invest 2005, II 5(3):765-773

143. Zhang L, Yu W, He T, Yu J, Caffrey RE, Dalmasso EA, Fu S, Pham T, Mei J, Ho J], Zhang W, Lopez P, Ho DD: Contribution of Human alpha -Defensin I, 2, and 3 to the Anti-HIV-I Activity of CD8 Antiviral Factor. Science 2002, 298(5595):995-1000.

144. Walker CM, Moody DJ, Stites DP, Levy JA: CD8+ lymphocytes can control HIV infection in vitro by suppressing virus replication. Science 1986, 234(4783): $1563-1566$.

145. Levy JA: The search for the CD8+ cell anti-HIV factor (CAF). Trends Immunol 2003, 24(I 2):628-632.

146. Mackewicz CE, Yuan J, Tran P, Diaz L, Mack E, Selsted ME, Levy JA: alpha-Defensins can have anti-HIV activity but are not CD8 cell anti-HIV factors. AIDS 2003, I 7( 1 4):F23-32.

147. Schutte BC, Mitros JP, Bartlett JA, Walters JD, Jia HP, Welsh MJ, Casavant TL, McCray PB Jr.: Discovery of five conserved beta defensin gene clusters using a computational search strategy. Proc Natl Acad Sci USA 2002, 99(4):2 129-2I 33.

148. Weinberg A, Quinones-Mateu ME, Lederman MM: Role of human beta-defensins in HIV infection. Adv Dent Res 2006, I ( (I):42-48. 
149. Sun L, Finnegan CM, Kish-Catalone T, Blumenthal R, Garzino-Demo P, La Terra Maggiore GM, Berrone S, Kleinman C, Wu Z, Abdelwahab S, Lu W, Garzino-Demo A: Human beta-defensins suppress human immunodeficiency virus infection: potential role in mucosal protection. J Virol 2005, 79(22): |43 I8-|4329.

I50. Feng Z, Dubyak GR, Lederman MM, Weinberg A: Cutting edge: human beta defensin 3--a novel antagonist of the HIV-I coreceptor CXCR4. J Immunol 2006, I 77(2):782-786.

I5I. Quinones-Mateu ME, Lederman MM, Feng Z, Chakraborty B, Weber J, Rangel HR, Marotta ML, Mirza M, Jiang B, Kiser P, Medvik K, Sieg SF, Weinberg A: Human epithelial beta-defensins 2 and 3 inhibit HIV-I replication. AIDS 2003, I 7( I 6):F39-48.

152. Sun L, Demasi L, Lafferty M, Goicochea M, Lu W, Garzino-Demo A: CCR6 mediates the intracellular HIV inhibitory activity of human beta-defensin 2. Retrovirology 2006, 3 Suppl I:S77.

153. Armogida SA, Yannaras NM, Melton AL, Srivastava MD: Identification and quantification of innate immune system mediators in human breast milk. Allergy Asthma Proc 2004, 25(5):297-304.

154. Jia HP, Starner T, Ackermann M, Kirby P, Tack BF, McCray PB Jr.: Abundant human beta-defensin-I expression in milk and mammary gland epithelium. J Pediatr 200 I, I38(I): I09-I I 2.

155. Kuhn L, Trabattoni D, Kankasa C, Semrau K, Kasonde P, Lissoni F, Sinkala M, Ghosh M, Vwalika C, Aldrovandi GM, Thea DM, Clerici M: Alpha-defensins in the prevention of HIV transmission among breastfed infants. J Acquir Immune Defic Syndr 2005, 39(2): $138-142$.

156. Braida L, Boniotto M, Pontillo A, Tovo PA, Amoroso A, Crovella S: A single-nucleotide polymorphism in the human beta-defensin I gene is associated with HIV-I infection in Italian children. AIDS 2004, I 8(I I): I598- I600.

157. Segat L, Milanese M, Boniotto M, Crovella S, Bernardon M, Costantini $M$, Alberico S: DEFB-I genetic polymorphism screening in HIV-I positive pregnant women and their children. J Matern Fetal Neonatal Med 2006, I 9(I): I3-16.

158. Milanese M, Segat L, Pontillo A, Arraes LC, de Lima Filho JL, Crovella S: DEFB I gene polymorphisms and increased risk of HIV-I infection in Brazilian children. AIDS 2006, 20(12): 1673-1675

159. Trabattoni D, Caputo SL, Maffeis G, Vichi F, Biasin M, Pierotti P, Fasano F, Saresella M, Franchini M, Ferrante P, Mazzotta F, Clerici M: Human alpha defensin in HIV-exposed but uninfected individuals. J Acquir Immune Defic Syndr 2004, 35(5):455-463.

160. Aldred PM, Hollox E], Armour JA: Copy number polymorphism and expression level variation of the human alpha-defensin genes DEFAI and DEFA3. Hum Mol Genet 2005, | 4( | 4):2045-2052.

16I. Hollox EJ, Armour JA, Barber JC: Extensive normal copy number variation of a beta-defensin antimicrobial-gene cluster. $\mathrm{Am} J$ Hum Genet 2003, 73(3):591-600.

162. Mars WM, Patmasiriwat P, Maity T, Huff V, Weil MM, Saunders GF: Inheritance of unequal numbers of the genes encoding the human neutrophil defensins HP-I and HP-3. J Biol Chem 1995, 270(5 I):3037I-30376.

163. Handschumacher RE, Harding MW, Rice J, Drugge RJ, Speicher DW: Cyclophilin: a specific cytosolic binding protein for cyclosporin A. Science 1984, 226(4674):544-547.

164. Sandstrom EG, Kaplan JC: Antiviral therapy in AIDS. Clinical pharmacological properties and therapeutic experience to date. Drugs 1987, 34(3):372-390.

165. Klatzmann D, Laporte JP, Achour A, Brisson E, Gruest J, Montagnier L, Gluckman JC: Functional inhibition by cyclosporin $A$ of the lymphocyte receptor for the AIDS virus (HIV). C R Acad Sci III 1986, 303(9):343-348.

166. Luban J, Bossolt KL, Franke EK, Kalpana GV, Goff SP: Human immunodeficiency virus type I Gag protein binds to cyclophilins A and B. Cell 1993, 73(6): 1067-1078.

167. Franke EK, Yuan HE, Luban J: Specific incorporation of cyclophilin A into HIV-I virions. Nature 1994, 372(6504):359-362.

168. Ott DE, Coren LV, Johnson DG, Sowder RC 2nd, Arthur LO, Henderson LE: Analysis and localization of cyclophilin $A$ found in the virions of human immunodeficiency virus type I MN strain. AIDS Res Hum Retroviruses 1995, I I (9): I003-1006.

169. Thali M, Bukovsky A, Kondo E, Rosenwirth B, Walsh CT, Sodroski J, Gottlinger HG: Functional association of cyclophilin A with HIV-I virions. Nature I994, 372(6504):363-365.

170. Besnier C, Takeuchi Y, Towers G: Restriction of lentivirus in monkeys. Proc Natl Acad Sci USA 2002, 99( I 8): I I920-I I 925.
17I. Cowan S, Hatziioannou T, Cunningham T, Muesing MA, Gottlinger HG, Bieniasz PD: Cellular inhibitors with FvI-like activity restrict human and simian immunodeficiency virus tropism. Proc Natl Acad Sci USA 2002, 99(I 8): I I9|4-II919.

172. Munk C, Brandt SM, Lucero G, Landau NR: A dominant block to HIV-I replication at reverse transcription in simian cells. Proc Natl Acad Sci USA 2002, 99(2 I ): I 3843-I 3848.

173. Hatziioannou T, Perez-Caballero D, Cowan S, Bieniasz PD: Cyclophilin interactions with incoming human immunodeficiency virus type I capsids with opposing effects on infectivity in human cells. J Virol 2005, 79(I): I76-183.

174. Sokolskaja E, Sayah DM, Luban J: Target cell cyclophilin A modulates human immunodeficiency virus type I infectivity. J Virol 2004, 78(23): I 2800-I2808.

I75. Luban J: Cyclophilin A, TRIM5, and Resistance to HIV-I Infection. J Virol 2006, 8 I(3): I054-106I.

176. Fischer G, Tradler T, Zarnt T: The mode of action of peptidyl prolyl cis/trans isomerases in vivo: binding vs. catalysis. FEBS Lett 1998, 426(I): 17-20.

177. Coaker G, Falick A, Staskawicz B: Activation of a phytopathogenic bacterial effector protein by a eukaryotic cyclophilin. Science 2005, 308(572I):548-550.

178. Stremlau M, Owens CM, Perron MJ, Kiessling M, Autissier P, Sodroski J: The cytoplasmic body component TRIM5alpha restricts HIV-I infection in Old World monkeys. Nature 2004, 427(6977):848-853.

179. Keckesova Z, Ylinen LM, Towers GJ: Cyclophilin A renders human immunodeficiency virus type I sensitive to Old World monkey but not human TRIM5 alpha antiviral activity. J Virol 2006, 80( 1 0):4683-4690.

180. Sokolskaja E, Berthoux L, Luban J: Cyclophilin A and TRIM5alpha independently regulate human immunodeficiency virus type I infectivity in human cells. J Virol 2006, 80(6):2855-2862.

18I. Stremlau M, Song B, Javanbakht H, Perron M, Sodroski J: Cyclophilin A: an auxiliary but not necessary cofactor for TRIM5alpha restriction of HIV-I. Virology 2006, 35 I (I): I I 2-I 20.

182. Speelmon EC, Livingston-Rosanoff D, Li SS, Vu Q, Bui J, Geraghty DE, Zhao LP, McElrath MJ: Genetic association of the antiviral restriction factor TRIM5alpha with human immunodeficiency virus type I infection. J Virol 2006, 80(5):2463-247I.

183. Javanbakht H, An P, Gold B, Petersen DC, O'Huigin C, Nelson GW, O'Brien S], Kirk GD, Detels R, Buchbinder S, Donfield S, Shulenin S, Song B, Perron MJ, Stremlau M, Sodroski J, Dean M, Winkler C: Effects of human TRIM5alpha polymorphisms on antiretroviral function and susceptibility to human immunodeficiency virus infection. Virology 2006, 354(I): I5-27.

184. Goldschmidt V, Bleiber G, May M, Martinez R, Ortiz M, Telenti A: Role of common human TRIM5alpha variants in HIV-I disease progression. Retrovirology 2006, 3:54.

185. Harris RS, Bishop KN, Sheehy AM, Craig HM, Petersen-Mahrt SK, Watt IN, Neuberger MS, Malim MH: DNA deamination mediates innate immunity to retroviral infection. Cell 2003, I I 3(6):803-809.

186. Mangeat B, Turelli P, Caron G, Friedli M, Perrin L, Trono D: Broad antiretroviral defence by human APOBEC3G through lethal editing of nascent reverse transcripts. Nature 2003 424(6944):99-103.

187. Zhang H, Yang B, Pomerantz RJ, Zhang C, Arunachalam SC, Gao L: The cytidine deaminase CEMI5 induces hypermutation in newly synthesized HIV-I DNA. Nature 2003, 424(6944):94-98.

188. Lecossier D, Bouchonnet F, Clavel F, Hance AJ: Hypermutation of HIV-I DNA in the absence of the Vif protein. Science 2003, 300(5622): IIII.

189. Mariani R, Chen D, Schrofelbauer B, Navarro F, Konig R, Bollman B, Munk C, Nymark-McMahon H, Landau NR: Species-specific exclusion of APOBEC3G from HIV-I virions by Vif. Cell 2003, I | 4(I):2|-3|

190. Yu Q, Konig R, Pillai S, Chiles K, Kearney M, Palmer S, Richman D, Coffin JM, Landau NR: Single-strand specificity of APOBEC3G accounts for minus-strand deamination of the HIV genome. Nat Struct Mol Biol 2004, I I (5):435-442.

191. Turelli P, Mangeat B, Jost S, Vianin S, Trono D: Inhibition of hepatitis B virus replication by APOBEC3G. Science 2004, 303(5665): 1829.

192. Newman EN, Holmes RK, Craig HM, Klein KC, Lingappa JR, Malim $\mathrm{MH}$, Sheehy AM: Antiviral function of APOBEC3G can be dis- 
sociated from cytidine deaminase activity. Curr Biol 2005, I5(2): 166-170.

193. Chiu YL, Witkowska HE, Hall SC, Santiago M, Soros VB, Esnault C, Heidmann T, Greene WC: High-molecular-mass APOBEC3G complexes restrict Alu retrotransposition. Proc Natl Acad Sci USA 2006, I03(42): I5588-I5593.

194. Schumacher AJ, Nissley DV, Harris RS: APOBEC3G hypermutates genomic DNA and inhibits Tyl retrotransposition in yeast. Proc Natl Acad Sci USA 2005, I02(28):9854-9859.

195. Esnault C, Heidmann O, Delebecque F, Dewannieux M, Ribet D, Hance AJ, Heidmann T, Schwartz O: APOBEC3G cytidine deaminase inhibits retrotransposition of endogenous retroviruses. Nature 2005, 433(7024):430-433.

196. Gu Y, Kodama H, Watanabe S, Kikuchi N, Ishitsuka I, Ozawa H, Fujisawa C, Shiga K: The first reported case of Menkes disease caused by an Alu insertion mutation. Brain Dev 2007, 29(2): 105-108.

197. Deininger PL, Batzer MA: Alu repeats and human disease. Mol Genet Metab 1999, 67(3):183-193.

198. Apoil PA, Kuhlein E, Robert A, Rubie H, Blancher A: HIGM syndrome caused by insertion of an AluYb8 element in exon I of the CD40LG gene. Immunogenetics 2007, 59(I): 17-23.

199. Marin M, Rose KM, Kozak SL, Kabat D: HIV-I Vif protein binds the editing enzyme APOBEC3G and induces its degradation. Nat Med 2003, 9(II): 1398-1403.

200. Yu X, Yu Y, Liu B, Luo K, Kong W, Mao P, Yu XF: Induction of APOBEC3G ubiquitination and degradation by an HIV-I VifCul5-SCF complex. Science 2003, 302(5647): $1056-1060$.

20I. Mehle A, Strack B, Ancuta P, Zhang C, McPike M, Gabuzda D: Vif overcomes the innate antiviral activity of APOBEC3G by promoting its degradation in the ubiquitin-proteasome pathway. J Biol Chem 2004, 279(9):7792-7798.

202. Mehle A, Goncalves J, Santa-Marta M, McPike M, Gabuzda D: Phosphorylation of a novel SOCS-box regulates assembly of the HIV-I Vif-Cul5 complex that promotes APOBEC3G degradation. Genes Dev 2004, I 8(23):286I-2866.

203. Hassaine G, Agostini I, Candotti D, Bessou G, Caballero M, Agut H, Autran B, Barthalay $Y$, Vigne R: Characterization of human immunodeficiency virus type I vif gene in long-term asymptomatic individuals. Virology 2000, 276(I):169-180.

204. Alexander L, Aquino-Dejesus M, Chan M, Andiman WA: Inhibition of human immunodeficiency virus type I (HIV-I) replication by two-amino-acid insertion in HIV-I vif from nonprogressing mother and child. J Virol 2002, 76(20): 10533-10539.

205. Farrow MA, Somasundaran M, Zhang C, Gabuzda D, Sullivan JL, Greenough TC: Nuclear localization of HIV type I Vif isolated from a long-term asymptomatic individual and potential role in virus attenuation. AIDS Res Hum Retroviruses 2005, 2 I (6):565-574.

206. An P, Bleiber G, Duggal P, Nelson G, May M, Mangeat B, Alobwede I, Trono D, Vlahov D, Donfield S, Goedert J], Phair J, Buchbinder S, O'Brien SJ, Telenti A, Winkler CA: APOBEC3G genetic variants and their influence on the progression to AIDS. J Virol 2004, 78(20): II070-II076.

207. Do H, Vasilescu A, Diop G, Hirtzig T, Heath SC, Coulonges C, Rappaport J, Therwath A, Lathrop M, Matsuda F, Zagury JF: Exhaustive genotyping of the CEMI 5 (APOBEC3G) gene and absence of association with AIDS progression in a French cohort. J Infect Dis 2005, $191(2): 159-163$.

208. Valcke HS, Bernard NF, Bruneau J, Alary M, Tsoukas CM, Roger M: APOBEC3G genetic variants and their association with risk of HIV infection in highly exposed Caucasians. AIDS 2006, 20(15): 1984-1986.

209. Jin X, Brooks A, Chen $H$, Bennett R, Reichman R, Smith $H$ : APOBEC3G/CEMI5 (hA3G) mRNA levels associate inversely with human immunodeficiency virus viremia. J Virol 2005, 79(17): II513-11516.

210. An P, Duggal P, Wang LH, O'Brien SJ, Donfield S, Goedert IJ, Phair J, Buchbinder S, Kirk GD, Winkler CA: Polymorphisms of CUL5 are associated with CD4+ $T$ cell loss in HIV-I infected individuals. PLoS Genet 2007, 3(I):el9.

21I. Varthakavi V, Smith RM, Bour SP, Strebel K, Spearman P: Viral protein $U$ counteracts a human host cell restriction that inhibits HIV-I particle production. Proc Natl Acad Sci USA 2003, I00(25): I5154-15159.

212. Neil S), Eastman SW, Jouvenet N, Bieniasz PD: HIV-I Vpu promotes release and prevents endocytosis of nascent retrovi- rus particles from the plasma membrane. PLoS Pathog 2006 , 2(5): 39

213. Hsu K, Seharaseyon J, Dong P, Bour S, Marban E: Mutual functional destruction of HIV-I Vpu and host TASK-I channel. Mol Cell 2004, I 4(2):259-267.

214. Strebel K: HIV-I Vpu: putting a channel to the TASK. Mol Cell 2004, I 4(2): I50-I52.

215. Akari H, Bour S, Kao S, Adachi A, Strebel K: The Human Immunodeficiency Virus Type I Accessory Protein Vpu Induces Apoptosis by Suppressing the Nuclear Factor kappaBdependent Expression of Antiapoptotic Factors. J Exp Med 200I, 194(9):1299-1312.

216. Margottin F, Bour SP, Durand H, Selig L, Benichou S, Richard V, Thomas D, Strebel K, Benarous R: A novel human WD protein, $\mathbf{h}$ beta TrCp, that interacts with HIV-I Vpu connects CD4 to ER degradation pathway through an F-box motif. Mol Cell 1998, 4:565-574.

217. Garrus JE, von Schwedler UK, Pornillos OW, Morham SG, Zavitz KH, Wang HE, Wettstein DA, Stray KM, Cote M, Rich RL, Myszka DG, Sundquist WI: TsgIOI and the vacuolar protein sorting pathway are essential for HIV-I budding. Cell 200I, I07(I):55-65

218. VerPlank L, Bouamr F, LaGrassa TJ, Agresta B, Kikonyogo A, Leis J, Carter CA: TsgI0I, a homologue of ubiquitin-conjugating (E2) enzymes, binds the $L$ domain in HIV type I Pr55(Gag). Proc Natl Acad Sci USA 200 I, 98( 14):7724-7729.

219. Martin-Serrano J, Zang T, Bieniasz PD: HIV-I and Ebola virus encode small peptide motifs that recruit Tsg IOI to sites of particle assembly to facilitate egress. Nat Med 200I, 7(12):1313-1319.

220. Welsch S, Keppler OT, Habermann A, Allespach I, Krijnse-Locker J, Krausslich HG: HIV-I buds predominantly at the plasma membrane of primary human macrophages. PLoS Pathog 2007, 3(3): $\mathrm{e} 6$.

22I. Jouvenet N, Neil SJ, Bess C, Johnson MC, Virgen CA, Simon SM, Bieniasz PD: Plasma membrane is the site of productive HIVI particle assembly. PLoS Biol 2006, 4( ( 2):e435.

222. Deneka M, Pelchen-Matthews A, Byland R, Ruiz-Mateos E, Marsh M: In macrophages, HIV-I assembles into an intracellular plasma membrane domain containing the tetraspanins CD8 I, CD9, and CD53. J Cell Biol 2007, I77(2):329-34I.

223. Morita E, Sundquist WI: Retrovirus budding. Annu Rev Cell Dev Biol 2004, 20:395-425.

224. von Schwedler UK, Stuchell M, Muller B, Ward DM, Chung HY, Morita E, Wang HE, Davis T, He GP, Cimbora DM, Scott A, Krausslich HG, Kaplan J, Morham SG, Sundquist WI: The protein network of HIV budding. Cell 2003, I I 4(6):70I-7I3

225. Amit I, Yakir L, Katz M, Zwang Y, Marmor MD, Citri A, Shtiegman K, Alroy I, Tuvia S, Reiss Y, Roubini E, Cohen M, Wides R, Bacharach E, Schubert U, Yarden Y: Tal, a Tsg I 0 I-specific E3 ubiquitin ligase, regulates receptor endocytosis and retrovirus budding. Genes Dev 2004, I 8(14): 1737-1752.

226. Eastman SW, Martin-Serrano J, Chung W, Zang T, Bieniasz PD: Identification of human VPS37C, a component of endosomal sorting complex required for transport-I important for viral budding. J Biol Chem 2005, 280(I):628-636.

227. Strack B Calistri A Craig S, Popova E, Gottlinger HG: AIPI/ALIX is a binding partner for HIV-I p6 and EIAV p9 functioning in virus budding. Cell 2003, I |4(6):689-699.

228. Stuchell MD, Garrus JE, Muller B, Stray KM, Ghaffarian S, McKinnon R, Krausslich HG, Morham SG, Sundquist WI: The human endosomal sorting complex required for transport (ESCRT-I) and its role in HIV-I budding. J Biol Chem 2004, 279(34):36059-36057I.

229. Bashirova AA, Bleiber G, Qi Y, Hutcheson H, Yamashita T, Johnson RC, Cheng J, Alter G, Goedert J], Buchbinder S, Hoots K, Vlahov D, May M, Maldarelli F, Jacobson L, O'Brien S J, Telenti A, Carrington M: Consistent effects of TSG I 0 I genetic variability on multiple outcomes of exposure to human immunodeficiency virus type I. J Virol 2006, 80( I 4):6757-6763.

230. Smith MS, Thresher RJ, Pagano JS: Inhibition of human immunodeficiency virus type I morphogenesis in T cells by alpha interferon. Antimicrob Agents Chemother 1991, 35(I):62-67.

23I. Yasuda Y, Miyake S, Kato S, Kita M, Kishida T, Kimura T, Ikuta K: Interferon-alpha treatment leads to accumulation of virus particles on the surface of cells persistently infected with the 
human immunodeficiency virus type I. J Acquir Immune Defic Syndr 1990, 3(I I): 1046-105I.

232. Okumura A, Lu G, Pitha-Rowe I, Pitha PM: Innate antiviral response targets HIV-I release by the induction of ubiquitinlike protein ISGI5. Proc Natl Acad Sci USA 2006, I03(5): | $440-1445$.

233. Dooher JE, Schneider BL, Reed JC, Lingappa JR: Host ABCEI is at Plasma Membrane HIV Assembly Sites and Its Dissociation from Gag is Linked to Subsequent Events of Virus Production. Traffic 2007, 8(3): 195-2II.

234. Lingappa JR, Dooher JE, Newman MA, Kiser PK, Klein KC: Basic residues in the nucleocapsid domain of $\mathrm{Gag}$ are required for interaction of HIV-I gag with ABCEI (HP68), a cellular protein important for HIV-I capsid assembly. J Biol Chem 2006, 28 I (7):3773-3784.

235. Zimmerman C, Klein KC, Kiser PK, Singh AR, Firestein BL, Riba SC, Lingappa JR: Identification of a host protein essential for assembly of immature HIV- I capsids. Nature 2002, 4I5(6867):88-92.

236. Dong X, Li H, Derdowski A, Ding L, Burnett A, Chen X, Peters TR, Dermody TS, Woodruff E, Wang JJ, Spearman P: AP-3 directs the intracellular trafficking of HIV-I Gag and plays a key role in particle assembly. Cell 2005, I 20(5):663-674.

237. Huizing M, Gahl WA: Disorders of vesicles of lysosomal lineage: the Hermansky-Pudlak syndromes. Curr Mol Med 2002, 2(5):45I-467.

238. Hammarstedt M, Garoff $\mathrm{H}$ : Passive and active inclusion of host proteins in human immunodeficiency virus type I gag particles during budding at the plasma membrane. J Virol 2004, 78(I I):5686-5697.

239. Tremblay MJ, Fortin JF, Cantin R: The acquisition of hostencoded proteins by nascent HIV-I. Immunol Today 1998, 19(8):346-35।.

240. Fortin JF, Cantin R, Lamontagne G, Tremblay M: Host-derived ICAM-I glycoproteins incorporated on human immunodeficiency virus type $I$ are biologically active and enhance viral infectivity. J Virol I997, 7 I(5):3588-3596.

24I. Bounou S, Leclerc JE, Tremblay MJ: Presence of host ICAM-I in laboratory and clinical strains of human immunodeficiency virus type I increases virus infectivity and CD4(+)-T- cell depletion in human lymphoid tissue, a major site of replication in vivo. J Virol 2002, 76(3): $1004-1014$.

242. Fortin JF, Cantin R, Bergeron MG, Tremblay MJ: Interaction between virion-bound host intercellular adhesion moleculeI and the high-affinity state of lymphocyte function-associated antigen-I on target cells renders $R 5$ and $X 4$ isolates of human immunodeficiency virus type $I$ more refractory to neutralization. Virology 2000, 268(2):493-503.

243. Fortin JF, Cantin R, Tremblay MJ: T cells expressing activated LFA-I are more susceptible to infection with human immunodeficiency virus type I particles bearing host-encoded ICAM-I. J Virol 1998, 72(3):2 105-2II2.

244. Losier M, Fortin JF, Cantin R, Bergeron MG, Tremblay MJ: Virionbound ICAM-I and activated LFA-I: a combination of factors conferring resistance to neutralization by sera from human immunodeficiency virus type I-infected individuals independently of the disease status and phase. Clin Immunol 2003, I08(2): III-II8.

245. Hioe CE, Chien PC Jr., Lu C, Springer TA, Wang XH, Bandres J, Tuen M: LFA-I expression on target cells promotes human immunodeficiency virus type I infection and transmission. I Virol 200I, 75(2): 1077-1082.

246. Tardif MR, Tremblay MJ: LFA-I is a key determinant for preferential infection of memory CD4+ T cells by human immunodeficiency virus type I. J Virol 2005, 79(2I): I37|4-13724.

247. Papa A, Danese S, Urgesi R, Grillo A, Guglielmo S, Roberto I, Semeraro S, Scaldaferri F, Pola R, Flex A, Fedeli G, Gasbarrini G, Pola P, Gasbarrini A: Intercellular adhesion molecule I gene polymorphisms in inflammatory bowel disease. Eur Rev Med Pharmacol Sci 2004, 8(5): |87-19|.

248. Hoxie JA, Fitzharris TP, Youngbar PR, Matthews DM, Rackowski JL, Radka SF: Nonrandom association of cellular antigens with HTLV-III virions. Hum Immunol I987, I 8(I):39-52.

249. Orentas RJ, Hildreth JE: Association of host cell surface adhesion receptors and other membrane proteins with HIV and SIV. AIDS Res Hum Retroviruses 1993, 9(I I): I I57-I I65.
250. Chan WL, Rodgers A, Grief C, Almond N, Ellis S, Flanagan B, Silvera P, Bootman J, Stott J, Kent K, et al.: Immunization with class I human histocompatibility leukocyte antigen can protect macaques against challenge infection with SIVmac-32H. AIDS 1995, 9(3):223-228.

25I. Arthur LO, Bess JW Jr., Urban RG, Strominger JL, Morton WR, Mann DL, Henderson LE, Benveniste RE: Macaques immunized with HLA-DR are protected from challenge with simian immunodeficiency virus. J Virol 1995, 69(5):3।17-3। 24.

252. Rossio JL, Bess J Jr., Henderson LE, Cresswell P, Arthur LO: HLA class II on HIV particles is functional in superantigen presentation to human T cells: implications for HIV pathogenesis. AIDS Res Hum Retroviruses 1995, I I ( 12 : : I 433- I 439.

253. Gurer C, Cimarelli A, Luban J: Specific incorporation of heat shock protein $\mathbf{7 0}$ family members into primate lentiviral virions. J Virol 2002, 76(9):4666-4670.

254. Yung E, Sorin M, Pal A, Craig E, Morozov A, Delattre O, Kappes J, Ott D, Kalpana GV: Inhibition of HIV-I virion production by a transdominant mutant of integrase interactor 1 . Nat Med 200I, 7(8):920-926.

255. Halwani R, Cen S, Javanbakht H, Saadatmand J, Kim S, Shiba K, Kleiman L: Cellular distribution of Lysyl-tRNA synthetase and its interaction with Gag during human immunodeficiency virus type I assembly. J Virol 2004, 78( I 4):7553-7564.

256. Javanbakht $H$, Halwani R, Cen S, Saadatmand J, Musier-Forsyth $K$, Gottlinger H, Kleiman L: The interaction between HIV-I Gag and human lysyl-tRNA synthetase during viral assembly. J Biol Chem 2003, 278(30):27644-2765I.

257. Kleiman $\mathrm{L}$, Halwani R, Javanbakht $\mathrm{H}$ : The selective packaging and annealing of primer tRNALys 3 in HIV-I. Curr HIV Res 2004, 2(2): $163-175$

258. Chertova E, Bess Jr JW Jr., Crise BJ, Sowder IR, Schaden TM, Hilburn JM, Hoxie JA, Benveniste RE, Lifson JD, Henderson LE, Arthur LO: Envelope glycoprotein incorporation, not shedding of surface envelope glycoprotein (gp I 20/SU), Is the primary determinant of SU content of purified human immunodeficiency virus type I and simian immunodeficiency virus. J Virol 2002, 76(II):5315-5325.

259. Freed EO, Martin MA: Virion incorporation of envelope glycoproteins with long but not short cytoplasmic tails is blocked by specific, single amino acid substitutions in the human immunodeficiency virus type I matrix. I Virol 1995, 69:1984-1989.

260. Freed EO, Martin MA: Domains of the human immunodeficiency virus type I matrix and gp4 I cytoplasmic tail required for envelope incorporation into virions. J Virol 1996, 70:34I-35I.

26I. Freed EO, Orenstein JM, Buckler White AJ, Martin MA: Single amino acid changes in the human immunodeficiency virus type I matrix protein block virus particle production. J Virol 1994, 68:5311-5320.

262. West JT, Weldon SK, Wyss S, Lin X, Yu Q, Thali M, Hunter E: Mutation of the dominant endocytosis motif in human immunodeficiency virus type I gp4I can complement matrix mutations without increasing Env incorporation. J Virol 2002, 76(7):3338-3349.

263. Blot G, Janvier K, Le Panse S, Benarous R, Berlioz-Torrent C: Targeting of the human immunodeficiency virus type I envelope to the trans-Golgi network through binding to TIP47 is required for env incorporation into virions and infectivity. J Virol 2003, 77( 1 2):6931-6945.

264. Lopez-Verges S, Camus G, Blot G, Beauvoir R, Benarous R, BerliozTorrent C: Tail-interacting protein TIP47 is a connector between Gag and Env and is required for Env incorporation into HIV-I virions. Proc Natl Acad Sci USA 2006, 103(40): | 4947-14952.

265. Lama J: The physiological relevance of CD4 receptor downmodulation during HIV infection. Curr HIV Res 2003, I: I67-I84.

266. Cortes MJ, Wong-Staal F, Lama J: Cell surface CD4 interferes with the infectivity of HIV-I particles released from $\mathrm{T}$ cells. J Biol Chem 2002, 277(3): I770-I 779.

267. Lama J, Mangasarian A, Trono D: Cell-surface expression of CD4 reduces HIV-I infectivity by blocking Env incorporation in a Nef- and Vpu-inhibitable manner. Curr Biol 1999, 9:622-631. 
268. Chen BK, Gandhi RT, Baltimore D: CD4 down-modulation during infection of human $T$ cells with human immunodeficiency virus type I involves independent activities of vpu, env, and nef. J Virol 1996, 70:6044-6053

269. Wildum S, Schindler M, Munch J, Kirchhoff F: Contribution of Vpu, Env, and Nef to CD4 down-modulation and resistance of human immunodeficiency virus type I-infected $T$ cells to superinfection. J Virol 2006, 80( I6):8047-8059.

270. Glushakova S, Munch J, Carl S, Greenough TC, Sullivan JL, Margolis L, Kirchhoff F: CD4 down-modulation by human immunodeficiency virus type I Nef correlates with the efficiency of viral replication and with CD4(+) T- cell depletion in human lymphoid tissue ex vivo. J Virol 200I, 75(2I): I0II3-I0II7.

27I. Lundquist CA, Tobiume M, Zhou J, Unutmaz D, Aiken C: Nef-mediated downregulation of CD4 enhances human immunodeficiency virus type I replication in primary $\mathbf{T}$ lymphocytes. J Virol 2002, 76(9):4625-4633.

272. Stoddart CA, Geleziunas R, Ferrell S, Linquist-Stepps V, Moreno ME, Bare C, Xu W, Yonemoto W, Bresnahan PA, McCune JM, Greene WC: Human immunodeficienty virus type I Nef-mediated downregulation of CD4 correlates with Nef enhancement of viral pathogenesis. J Virol 2003, 77(3):2/24-2/33.

273. Arganaraz ER, Schindler M, Kirchhoff F, Cortes MJ, Lama J: Enhanced CD4 down-modulation by late-stage HIV-I nef alleles is associated with increased Env incorporation and viral replication. I Biol Chem 2003, 36:339|2-339/9.

274. Carl S, Greenough TC, Krumbiegel M, Greenberg M, Skowronski J, Sullivan JL, Kirchhoff F: Modulation of different human immunodeficiency virus type I nef functions during progression to AIDS. J Virol 200I, 75(8):3657-3665.

275. Brambilla A, Turchetto L, Gatti A, Bovolenta C, Veglia F, Santagostino E, Gringeri A, Clementi M, Poli G, Bagnarelli P, Vicenzi E: Defective nef alleles in a cohort of hemophiliacs with progressing and nonprogressing HIV-I infection. Virology 1999, 259(2):349-368.

276. Geffin R, Wolf D, Muller R, Hill MD, Stellwag E, Freitag M, Sass G, Scott GB, Baur AS: Functional and structural defects in HIV type I nef genes derived from pediatric long-term survivors. AIDS Res Hum Retroviruses 2000, I6(17): 1855-1868.

277. Rhodes DI, Ashton L, Solomon A, Carr A, Cooper D, Kaldor J, Deacon N: Characterization of three nef-defective human immunodeficiency virus type I strains associated with long-term nonprogression. Australian Long-Term Nonprogressor Study Group. J Virol 2000, 74(22): $10581-10588$

278. Tobiume M, Takahoko M, Yamada T, Tatsumi M, Iwamoto A, Matsuda $M$ : Inefficient enhancement of viral infectivity and CD4 downregulation by human immunodeficiency virus type Nef from Japanese long-term nonprogressors. J Virol 2002, 76(I 2):5959-5965.

279. Coleman SH, Day JR, Guatelli J: The HIV-I Nef protein as a target for antiretroviral therapy. Emerg Ther Targets 200I, 5(I): I-22.

280. Kedzierska K, Crowe SM: Cytokines and HIV-I: interactions and clinical implications. Antivir Chem Chemother 200I, 12(3): 133-150.

28I. Jacques C, Gosset M, Berenbaum F, Gabay C: The role of IL-I and IL-I Ra in joint inflammation and cartilage degradation. Vitam Horm 2006, 74:37I-403.

282. Do H, Vasilescu A, Carpentier W, Meyer L, Diop G, Hirtzig T, Coulonges C, Labib T, Spadoni JL, Therwath A, Lathrop M, Matsuda F, Zagury JF: Exhaustive genotyping of the interleukin-I family genes and associations with AIDS progression in a French cohort. J Infect Dis 2006, 194(I I): I 492-I504.

283. Kinter A, Fauci AS: Interleukin-2 and human immunodeficiency virus infection: pathogenic mechanisms and potential for immunologic enhancement. Immunol Res 1996, I 5(I): I-I5.

284. Shrestha S, Strathdee SA, Galai N, Oleksyk T, Fallin MD, Mehta S, Schaid D, Vlahov D, O'Brien SJ, Smith MW: Behavioral risk exposure and host genetics of susceptibility to HIV-I infection. J Infect Dis 2006, 193(I): 16-26.

285. Modi WS, O'Brien TR, Vlahov D, Buchbinder S, Gomperts E, Phair J, O'Brien SJ, Winkler C: Haplotype diversity in the interleukin-4 gene is not associated with HIV-I transmission and AIDS progression. Immunogenetics 2003, 55(3):157-164.

286. Vasilescu A, Heath SC, Ivanova R, Hendel H, Do H, Mazoyer A, Khadivpour E, Goutalier FX, Khalili K, Rappaport J, Lathrop GM, Matsuda F, Zagury JF: Genomic analysis of ThI-Th2 cytokine genes in an AIDS cohort: identification of IL4 and ILI 0 haplotypes associated with the disease progression. Genes Immun 2003, 4(6):44I-449.

287. Soriano A, Lozano F, Oliva H, Garcia F, Nomdedeu M, De Lazzari $E$ Rodriguez C, Barrasa A, Lorenzo JI, Del Romero J, Plana M, Miro JM, Gatell JM, Vives J, Gallart T: Polymorphisms in the interleukin-4 receptor alpha chain gene influence susceptibility to HIV-I infection and its progression to AIDS. Immunogenetics 2005, 57(9):644-654

288. Maciaszek JW, Parada NA, Cruikshank WW, Center DM, Kornfeld H, Viglianti GA: IL-I 6 represses HIV-I promoter activity. J Immunol 1997, I 58(I):5-8

289. Zhou P, Goldstein S, Devadas K, Tewari D, Notkins AL: Human CD4+ cells transfected with IL-16 CDNA are resistant to HIV-I infection: inhibition of mRNA expression. Nat Med 1997, 3(6):659-664.

290. Kornfeld H, Cruikshank WW: Prospects for IL- 16 in the treatment of AIDS. Expert Opin Biol Ther 200I, I(3):425-432.

291. Scala E, D'Offizi G, Rosso R, Turriziani O, Ferrara R, Mazzone AM, Antonelli G, Aiuti F, Paganelli R: C-C chemokines, IL-16, and soluble antiviral factor activity are increased in cloned $\mathbf{T}$ cells from subjects with long-term nonprogressive HIV. infection. J Immunol 1997, I 58(9):4485-4492.

292. Amiel C, Darcissac E, Truong MJ, Dewulf J, Loyens M, Mouton Y, Capron A, Bahr GM: Interleukin-16 (IL-16) inhibits human immunodeficiency virus replication in cells from infected subjects, and serum IL- 16 levels drop with disease progression. J Infect Dis 1999, 179(I):83-91.

293. Bader A, Brockmeyer N, Schnaitmann E, Mertins L, Otteken A, Kurth $R$, Werner $A$ : Interleukin- 16 serum levels during the course of HIV-I infection. AIDS 200I, I 5(4):528-529.

294. Nakayama EE, Wasi C, Ajisawa A, Iwamoto A, Shioda T: A new polymorphism in the promoter region of the human interleukin-I6 (IL-16) gene. Genes Immun 2000, I (4):293-294.

295. Stylianou E, Bjerkeli V, Yndestad A, Heggelund L, Waehre T, Damas JK, Aukrust P, Froland SS: Raised serum levels of interleukin- 18 is associated with disease progression and may contribute to virological treatment failure in HIV-I-infected patients. Clin Exp Immunol 2003, I 32(3):462-466.

296. Wiercinska-Drapalo A, Jaroszewicz J, Flisiak R, Prokopowicz D: Plasma interleukin- 18 is associated with viral load and disease progression in HIV-I-infected patients. Microbes Infect 2004, 6( I 4): I273-1277.

297. Torre D, Pugliese A: Interleukin- 18: a proinflammatory cytokine in HIV-I infection. Curr HIV Res 2006, 4(4):423-430.

298. Segat L, Bevilacqua D, Boniotto M, Arraes LC, de Souza PR, de Lima Filho JL, Crovella S: IL-I8 gene promoter polymorphism is involved in HIV-I infection in a Brazilian pediatric population. Immunogenetics 2006, 58(5-6):47I-473.

299. Song W, Wilson CM, Allen S, Wang C, Li Y, Kaslow RA, Tang J: Interleukin 18 and human immunodeficiency virus type $I$ infection in adolescents and adults. Clin Exp Immunol 2006, 144(I): I 17-124.

300. Biron CA: Role of early cytokines, including alpha and beta interferons (IFN-alpha/beta), in innate and adaptive immune responses to viral infections. Semin Immunol 1998, I0(5):383-390.

30I. Diop G, Hirtzig T, Do H, Coulonges C, Vasilescu A, Labib T, Spadoni JL, Therwath A, Lathrop M, Matsuda F, Zagury JF: Exhaustive genotyping of the interferon alpha receptor I (IFNARI) gene and association of an IFNARI protein variant with AIDS progression or susceptibility to HIV-I infection in a French AIDS cohort. Biomed Pharmacother 2006, 60(9):569-577.

302. Bafica A, Scanga CA, Schito M, Chaussabel D, Sher A: Influence of coinfecting pathogens on HIV expression: evidence for a role of Toll-like receptors. J Immunol 2004, I 72( I 2):7229-7234.

303. Finberg RW, Wang JP, Kurt-Jones EA: Toll like receptors and viruses. Rev Med Virol 2007, 17(I):35-43.

304. Bentwich Z, Kalinkovich A, Weisman Z: Immune activation is a dominant factor in the pathogenesis of African AIDS. Immunol Today 1995, 16(4): I87-19|.

305. Quinn TC, Piot P, McCormick JB, Feinsod FM, Taelman H, Kapita B, Stevens W, Fauci AS: Serologic and immunologic studies in patients with AIDS in North America and Africa. The potential role of infectious agents as cofactors in human immunodeficiency virus infection. JAMA 1987, 257(19):2617-2621. 
306. Akira S: TLR signaling. Curr Top Microbiol Immunol 2006, 3 I I: I - I6.

307. Pomerantz RJ, Feinberg MB, Trono D, Baltimore D: Lipopolysaccharide is a potent monocyte/macrophage-specific stimulator of human immunodeficiency virus type I expression. J Exp Med 1990, I 72(I):253-26I.

308. Schlaepfer E, Audige A, Joller H, Speck RF: TLR7/8 triggering exerts opposing effects in acute versus latent HIV infection. J Immunol 2006, I 76(5):2888-2895.

309. Agrawal S, Martin RR: Was induction of HIV-I through TLR9? J Immunol 2003, I7I(4): I62I.

310. Bafica A, Scanga CA, Schito ML, Hieny S, Sher A: Cutting edge: in vivo induction of integrated HIV-I expression by mycobacteria is critically dependent on Toll-like receptor 2 . J Immunol 2003, I 7 I(3): I I 23-I I 27.

3। I. Equils O, Faure E, Thomas L, Bulut Y, Trushin S, Arditi M: Bacterial lipopolysaccharide activates HIV long terminal repeat through Toll-like receptor 4. J Immunol 200 I, I 66(4):2342-2347.

312. Equils O, Schito ML, Karahashi H, Madak Z, Yarali A, Michelsen KS Sher A, Arditi M: Toll-like receptor 2 (TLR2) and TLR9 signaling results in HIV-long terminal repeat trans-activation and HIV replication in HIV-I transgenic mouse spleen cells: implications of simultaneous activation of TLRs on HIV replication. J Immunol 2003, I 70( I 0):5 I59-5I64.

313. Sundstrom JB, Little DM, Villinger F, Ellis JE, Ansari AA: Signaling through Toll-like receptors triggers HIV-I replication in latently infected mast cells. J Immunol 2004, I 72(7):439|-440I.

3 14. Toossi Z: Virological and immunological impact of tuberculosis on human immunodeficiency virus type I disease. J Infect Dis 2003, I 88(8): I |46- I I55.

315. Agrawal S: Importance of nucleotide sequence and chemical modifications of antisense oligonucleotides. Biochim Biophys Acta 1999, 1489(I):53-68.

316. Lisziewicz J, Sun D, Weichold FF, Thierry AR, Lusso P, Tang J, Gallo RC, Agrawal S: Antisense oligodeoxynucleotide phosphorothioate complementary to Gag mRNA blocks replication of human immunodeficiency virus type I in human peripheral blood cells. Proc Natl Acad Sci USA 1994, 9 I (I 7):7942-7946.

317. Bochud PY, Hersberger M, Taffe P, Bochud M, Stein CM, Rodrigues SD, Calandra T, Francioli P, Telenti A, Speck RF, Aderem A: Polymorphisms in Toll-like receptor 9 influence the clinical course of HIV-I infection. AIDS 2007, 2 I (4):44 I-446.

318. Abu-Raddad LJ, Patnaik P, Kublin JG: Dual infection with HIV and malaria fuels the spread of both diseases in sub-Saharan Africa. Science 2006, 3 I4(5805): 1603-1606.

319. Kublin IG, Patnaik P, Jere CS, Miller WC, Hoffman IF, Chimbiya N, Pendame R, Taylor TE, Molyneux ME: Effect of Plasmodium falciparum malaria on concentration of HIV-I-RNA in the blood of adults in rural Malawi: a prospective cohort study. Lancet 2005, 365(9455):233-240.

320. Patnaik P, Jere CS, Miller WC, Hoffman IF, Wirima J, Pendame R, Meshnick SR, Taylor TE, Molyneux ME, Kublin JG: Effects of HIV-I serostatus, HIV-I RNA concentration, and CD4 cell count on the incidence of malaria infection in a cohort of adults in rural Malawi. J Infect Dis 2005, I 92(6):984-99I.

321. Gallagher M, Malhotra I, Mungai PL, Wamachi AN, Kioko JM, Ouma $\mathrm{J}$, Muchiri E, King CL: The effects of maternal helminth and malaria infections on mother-to-child HIV transmission. AIDS 2005, I9(16): I849-1855.

322. Kannangara S, DeSimone JA, Pomerantz RJ: Attenuation of HIV-I infection by other microbial agents. J Infect Dis 2005, 192(6): 1003-1009.

323. Grivel JC, Ito Y, Faga G, Santoro F, Shaheen F, Malnati MS, Fitzgerald W, Lusso P, Margolis L: Suppression of CCR5- but not CXCR4tropic HIV-I in lymphoid tissue by human herpesvirus 6. Nat Med 200I, 7(I I): I232-I235.

324. Lisco A, Grivel JC, Biancotto A, Vanpouille C, Origgi F, Malnati MS, Schols D, Lusso $\mathrm{P}$, Margolis LB: Viral interactions in human lymphoid tissue: Human herpesvirus 7 suppresses the replication of CCR5-tropic human immunodeficiency virus type I via CD4 modulation. J Virol 2007, 8 I(2):708-7I7.

325. Wallace $\mathrm{PK}$, Howell AL, Fanger MW: Role of Fc gamma receptors in cancer and infectious disease. I Leukoc Biol 1994, 55(6):816-826.

326. Brouwer KC, Lal RB, Mirel LB, Yang C, van Eijk AM, Ayisi J, Otieno J, Nahlen BL, Steketee R, Lal AA, Shi YP: Polymorphism of Fc recep- tor Ila for IgG in infants is associated with susceptibility to perinatal HIV-I infection. AIDS 2004, I 8(8): I I87-I I 94.

327. Shi YP, Nahlen BL, Kariuki S, Urdahl KB, McElroy PD, Roberts JM, Lal AA: Fcgamma receptor Ila (CD32) polymorphism is associated with protection of infants against high-density Plasmodium falciparum infection. VII. Asembo Bay Cohort Project. J Infect Dis 200I, I 84(I):I07-III.

328. Griffiths GM: Protein sorting and secretion during CTL killing. Semin Immunol 1997, 9(2): 109-1 I5.

329. Migueles SA, Laborico AC, Shupert WL, Sabbaghian MS, Rabin R, Hallahan CW, Van Baarle D, Kostense S, Miedema F, McLaughlin M, Ehler L, Metcalf J, Liu S, Connors M: HIV-specific CD8 T cell proliferation is coupled to perforin expression and is maintained in nonprogressors. Nature 2002, 3(I I): I06 I-1068.

330. Mcllroy D, Meyer L, Dudoit Y, Samri A, Delfraissy JF, Autran B, Debre $P$, Theodorou I: Polymorphism in the proximal promoter region of the perforin gene and its impact on the course of HIV infection. Int J Immunogenet 2006, 33(2):73-79.
Publish with Bio Med Central and every scientist can read your work free of charge

"BioMed Central will be the most significant development for disseminating the results of biomedical research in our lifetime. "

Sir Paul Nurse, Cancer Research UK

Your research papers will be:

- available free of charge to the entire biomedical community

- peer reviewed and published immediately upon acceptance

- cited in PubMed and archived on PubMed Central

- yours - you keep the copyright 